\title{
What was an interglacial river like? Sedimentological investigation of Holsteinian fluvial deposits in eastern Poland
}

\author{
Tomasz ZIELIŃSKI ${ }^{1, *}$, Sławomir TERPIŁOWSKI ${ }^{2}$, Paweł ZIELIŃSKI ${ }^{2}$, Irena A. PIDEK², \\ Anna GODLEWSKA ${ }^{2}$ and Piotr CZUBLA ${ }^{3}$ \\ 1 Adam Mickiewicz University, Institute of Geology, Maków Polnych 16, 61-606 Poznań, Poland \\ 2 Maria Skłodowska-Curie University, Department of Geoecology and Palaeogeography, Kraśnicka 2c, d, 20-718 Lublin, \\ Poland \\ 3 Łódź University, Laboratory of Geology, Narutowicza 88, 90-139 Łódź, Poland
}

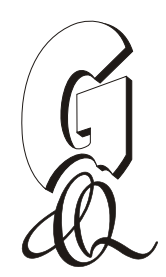

Zieliński, T., Terpiłowski, S., Zieliński, P., Pidek, I.A., Godlewska, A., Czubla, P., 2016. What was an interglacial river like? Sedimentological investigation of Holsteinian fluvial deposits in eastern Poland. Geological Quarterly, 60 (1): 149-166, doi: $10.7306 / g q .1250$

Holsteinian fluvial deposits in the Samica River valley in eastern Poland have been studied, in an approximately $12 \mathrm{~m}$ thick succession filling palaeochannels and comprising sandy channel facies succeeded by a package of gyttja, peat and silt deposited in an oxbow lake. Channel belts including palaeochannel fills cut into outwash sands and are overlain by diamictic sands reworked by gelifluction under periglacial conditions. Sedimentological and palynological investigations in combination allowed the recognition of glacial and interglacial deposits. The channel belt was formed by a typical sand-bed, meandering river with deposition controlled by abundant point bars. The sedimentary evolution of the Samica valley is interpreted in the context of the glacial-interglacial cycle. Valley-scale erosion and change of river style from braided to meandering occurred coevally with the decay of an ice sheet (deglaciation) and the main phase of meandering river sedimentation is attributed to the latest Elsterian and early Holsteinian. The next part of the interglacial, from pioneer stage to established temperate conditions, is recorded in a biogenic oxbow-lake fill. The succession studied has been compared with published data on the European fluvial deposits of Middle Pleistocene interglacials. It is pointed out here that river channel patterns in Western and Eastern Europe differed. Based on this observation, some general hypotheses regarding continental-scale climatic distinctness are put forward.

Key words: sedimentology, meandering river, palaeoclimate, Pleistocene, MIS 11, Poland.

\section{INTRODUCTION}

Sedimentological analyses play an important part in palaeoenvironmental and lithostratigraphical interpretations of Quaternary fluvial deposits, as demonstrated by European studies of deposits of Weichselian and Holocene age. Such fluvial sedimentary records have been recognized in detail in the Netherlands (Van Huissteden, 1990; Kasse et al., 1995; Weerts and Berendsen, 1995; Huisink, 2000; Mol et al., 2000; Busschers et al., 2007; Hijma and Cohen, 2011), the British Isles (Brown, 1995; Rose, 1995; Collins et al., 1996; Gao et al., 2007), Germany (Mol, 1995, 1997; Mol et al., 2000; Andres et al., 2001; Dambeck and Thiemeyer, 2002; Kasse et al., 2003; Erkens et al., 2011), northern France (Lefevre et al., 1995; Straffin et al., 2000; Antoine et al., 2003) and in Poland (Szumański, 1983; Rotnicki, 1987; Kozarski et al., 1988;

* Corresponding author, e-mail: zielu@amu.edu.pl

Received: April 5, 2015; accepted: June 19, 2015; first published online: September 16, 2015
Turkowska, 1988; Vandenberghe et al., 1994; Kalicki, 1996; Florek, 1997; Starkel, 2002; Starkel et al., 2007; Gębica, 2004). Several studies have been conducted in Eastern Europe as well, e.g. in Belarus (Kalicki and Sanko, 1998) and Russia (Sidorchuk et al., 2001, 2009; Panin and Matlakhova, 2015). Most of these papers deal with the problem of fluvial transition controlled by cold-to-temperate climatic change.

The number of such studies contrasts greatly with sporadic accounts of river development during the older glacial-interglacial cycles (Veldkamp and Van den Berg, 1993; Krzyszkowski, 1996; Turner, 1998; Marks and Pochocka, 1999; Antoine et al., 2000; Zieliński and Goździk, 2001; Gibbard and Lewin 2002; Marks and Pavlovskaya, 2003; Busschers et al., 2007; Lewin and Gibbard, 2010; Cordier et al., 2014). Only sporadic studies focused on interpretations of the interglacial river environment. The current analysis is intended to help fill this gap. Moreover, the authors believe that their research can shed light on the evolution of the Central European fluvial systems during the Holsteinian, which is correlated in Poland with Marine Isotope Stage 11 (MIS 11; Lindner et al., 2013).

Only rarely can fluvial deposits of former interglacials be studied in outcrop because they are buried under thick successions of younger age. Moreover, interglacial fluvial series have 


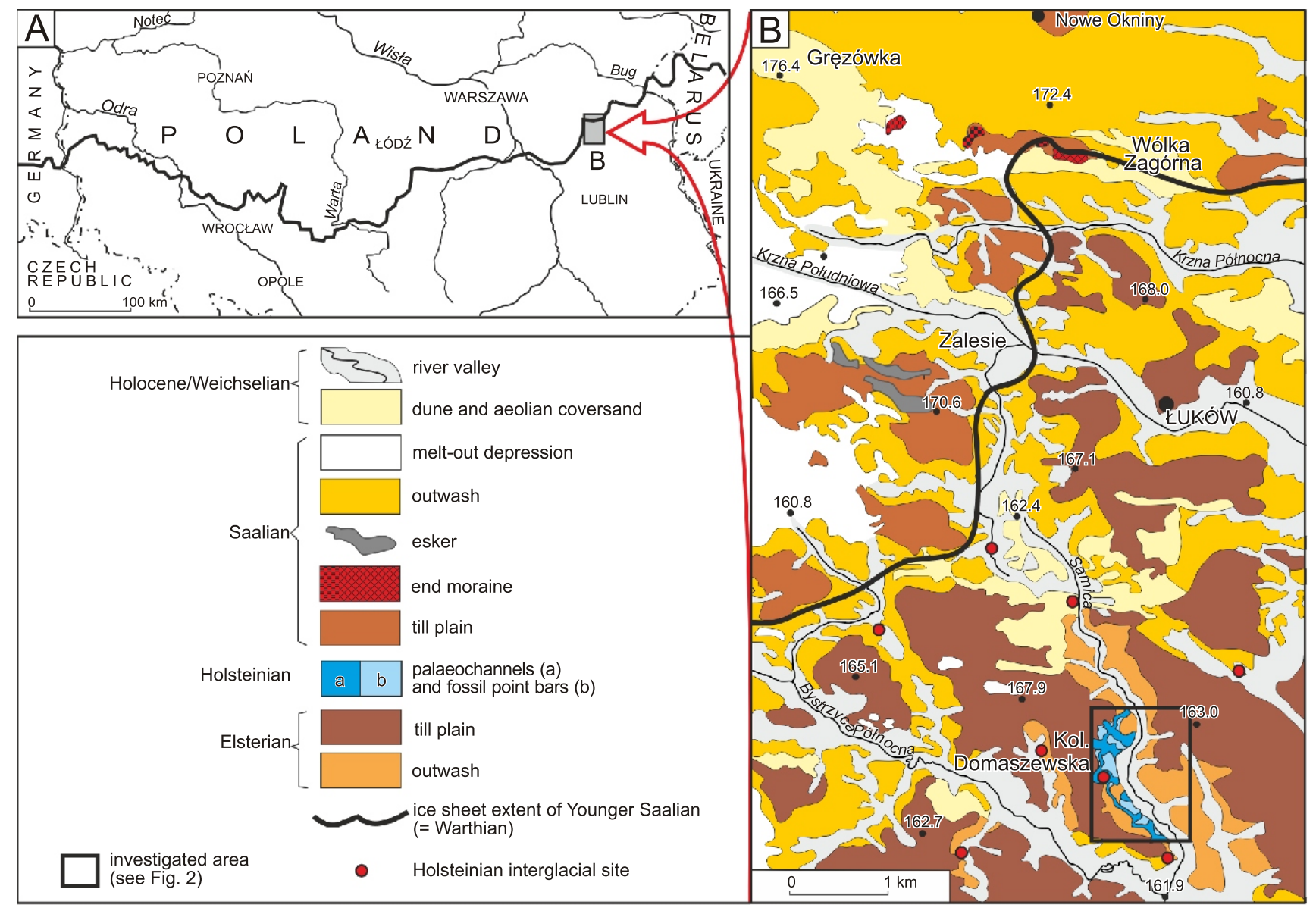

Fig. 1. The Łuków area

A - location of the study area, showing also the extent of the Younger Saalian (= Warthian) ice sheet; B - geomorphological sketch of the glaciomarginal zone; the numbers indicate terrain elevations

a low preservation potential due to erosion at the transition to the next glacial (Vandenberghe, 2008). This is why our knowledge of fluvial evolution during former interglacial periods has to overcome the relative sparsity of the preserved record.

In eastern Poland, on the Central European Plain, $80 \mathrm{~km}$ from the border with Belarus (Fig. 1), Holsteinian deposits occur close to the surface in the Samica valley. They are exploited in a few excavations in the neighbourhood of the town of Łuków. This has offered a unique opportunity for studying the interglacial fluvial succession. These deposits have been researched in terms of their stratigraphic position (Terpiłowski et al., 2014), however, their detailed palaeoenvironmental interpretation was lacking.

The present paper aims: (1) to define the lithological features of interglacial fluvial deposits by comparison with glaciofluvial ones, which occur in the same valley. In this way an evaluation of typical interglacial lithofacies can be made; (2) to interpret the sedimentary environment of the interglacial valley; (3) to track fluvial system evolution in the glacial-interglacial cycle; (4) to find the main governing agents of braided-to-meandering fluvial pattern change; (5) to compare our results with equivalents from other European Holsteinian sites. This can help us understand some interglacial palaeoclimatic conditions of our continent at the beginning of this warm stage.

\section{GEOLOGICAL AND GEOMORPHOLOGICAL SETTING}

Fluvial deposits of Holsteinian age were found in numerous boreholes close to Łuków (eastern Poland). All these sites are located south of the line of the Younger Saalian (= Warthian MIS 6) ice sheet extent, in the valleys of the Bystrzyca Północna catchment (Fig. 1; Małek and Buczek, 2009). Interglacial successions in this region usually are overlain by a thin (up to $2 \mathrm{~m}$ ) cover of Saalian glaciofluvial and/or Weichselian-Holocene (MIS 5d-1) fluvial deposits (Małek and Pidek, 2007). There is only one area where interglacial deposits crop out at the surface - the surroundings of Kolonia Domaszewska (Fig. 1B). They fringe $5 \mathrm{~km}$ of the western margin of Samica valley, within a terrace 4 metres above the Holocene floodplain (Fig. 2). These deposits fill a deep (up to $20 \mathrm{~m}$ ) incision eroded in glaciogenic forms of Elsterian age (MIS 12): a till plain consisting of basal till and sandy-gravelly outwash (Fig. 2B). Petrographic analysis indicates that the basal till contains indicator erratics typical of south-west and central Fennoscandia (Åland, Småland and Blekinge, Dalarna). On the basis of geographical coordinates of indicator rock outcrops in Fennoscandia the TBC coefficient was calculated (Theoretical Boulder Centre - the middle point of the source areas; see Lüttig, 1958; Vinx et al., 1997; Czubla, 

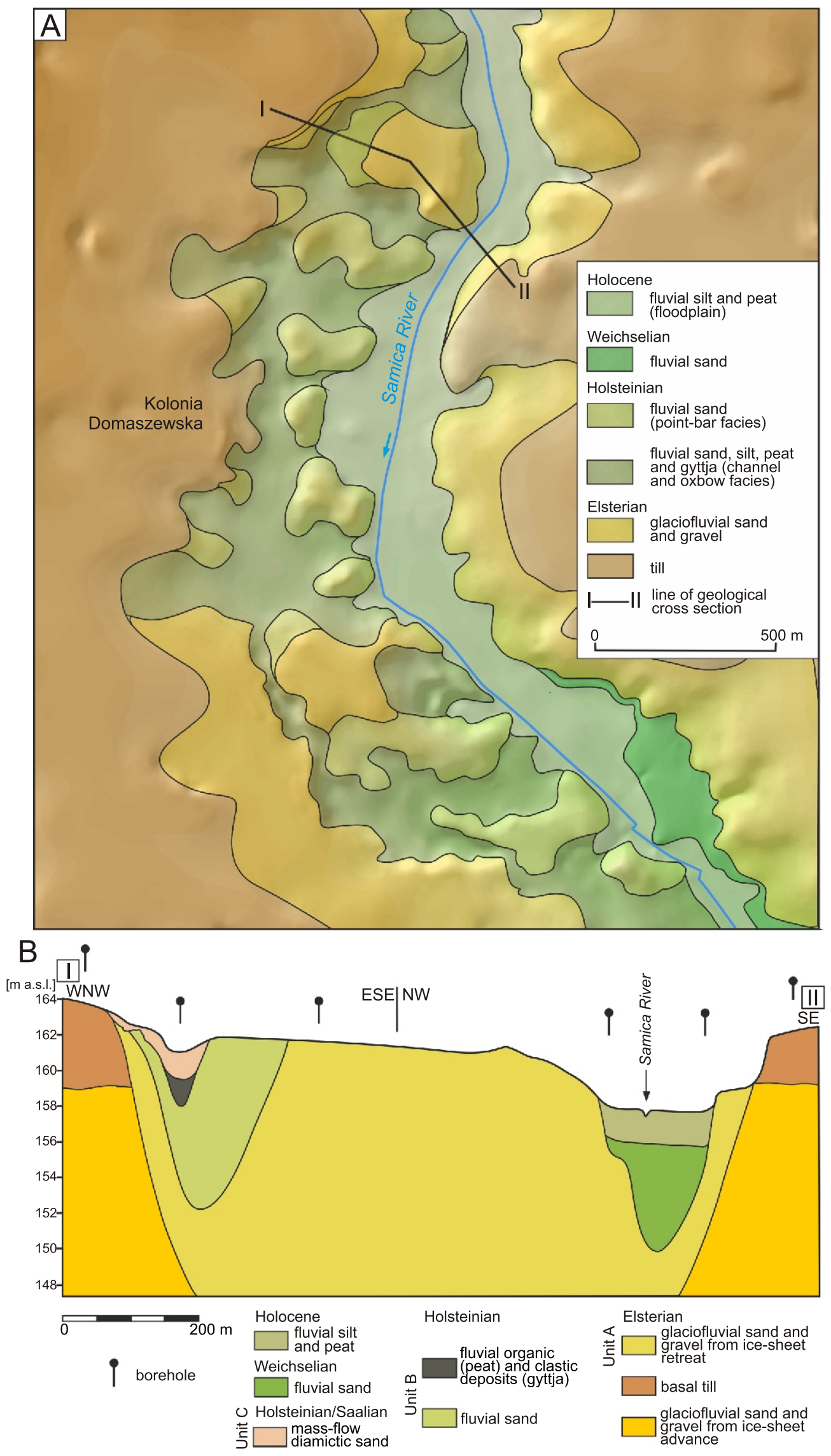

Fig. 2. Geology of the Samica valley

A - geological sketch, location of cross-section is marked; B - geological cross-section 
2001). The TBC of the till is situated on the Baltic coast in the south-eastern surroundings of Stockholm $\left(18.29^{\circ} \mathrm{E}\right.$ and $\left.59.13^{\circ} \mathrm{N}\right)$. Its position is similar to that calculated for the tills of the Elsterian Glaciation (MIS 12) studied in central-eastern Poland (Czubla, 2015).

Holsteinian fluvial clastic deposits of the Samica valley (unit $B$ in this study) were dated by $\mathrm{TL}_{\mathrm{MAX}}$ method at $412-445 \mathrm{ka}$ (Terpiłowski et al., 2014), i.e. latest Elsterian and earliest Holsteinian. The organo-clastic package (gyttja, peat and silt), present in the upper part of the interglacial fluvial interval, has been analysed palynologically (Pidek et al., 2014). The pollen spectra show a succession through five local pollen assemblage zones (L PAZ): Betula-Juniperus-Betula nana L PAZ, Pinus-Betula-Larix L PAZ, Picea-Alnus-Fraxinus-/Ulmus/ L PAZ, Taxus-Quercus-Abies-/Carpinus/ L PAZ (with thermophilous plants, among others Pterocarya, which was not present in younger interglacials; see Krupiński, 2000) and Pinus L PAZ. The first four L PAZs are correlated with local macrofossil zones (L MAZ): Ranunculus sceleratus-Urtica dioica-Carex rostrata LMAZ, Carex rostrata-Urtica dioica LMAZ, Carex rostrata-Urtica dioica-Ranunculus sceleratus-Nuphar LMAZ, Salvinia natans-Azolla filiculoides LMAZ. These zones reflect vegetational succession from open boreal communities with birches and abundant sedges and grasses to wet forest of different types (riparian forests, spruce and alder ones, alder carr with yew), followed by fir forests and dry-ground forests dominated by hornbeam and oak (Terpiłowski et al., 2014). The succession described indicates that the climate became successively warmer and wetter, typical of the older part of the Holsteinian Interglacial in central-eastern Poland (Krupiński, 2000; Nitychoruk et al., 2005; Pidek et al., 2011). The considerable share of shrubs (Juniperus and Salix) and wet meadow-like communities, which might have been overgrowing the Samica floodplain, throughout the first part of interglacial warming is noticeable.

The uppermost part of fluvial deposits passes laterally and vertically to diamictic gravelly sands in the marginal zone of the valley (unit $\mathrm{C}$ on Fig. 2B). This geological situation suggests that the alluviation was replaced by mass-flow processes with time. It is correlated with the Pinus L PAZ, which indicates climatic cooling at the end of interglacial.

\section{METHODS}

Deposits that fill the valley have been analysed sedimentologically in three exposures (sites: Samica I, II and III) situated along the western flank of the Samica valley (Fig. 3). In 2011-2012, 31 sections were documented in three excavations. Furthermore, 42 boreholes of up to $15 \mathrm{~m}$ deep were made

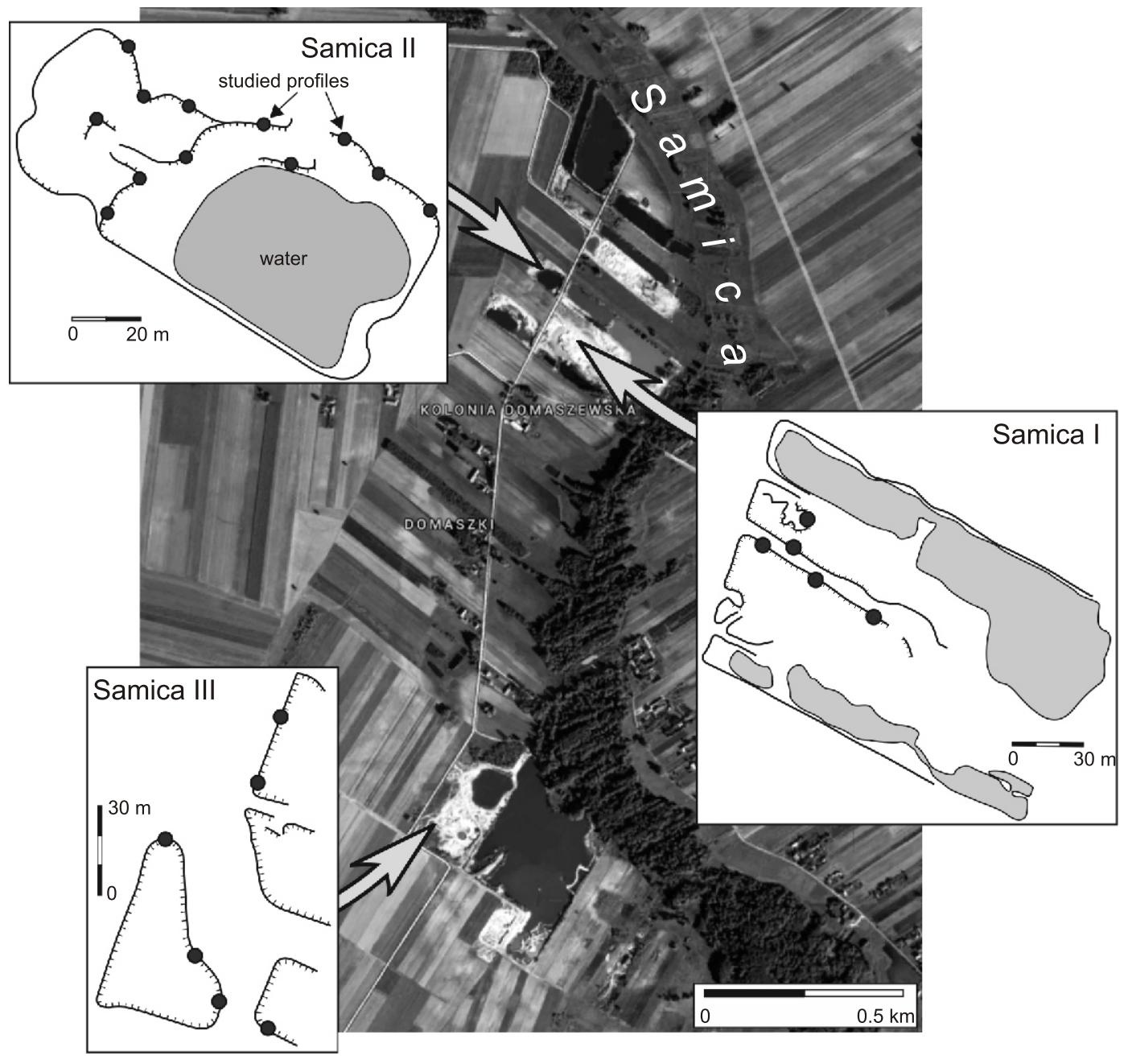

Fig. 3. Excavations under study 
to trace the course and lithological infill of the palaeochannels. The texture, structure, thickness, shape, extent of depositional bodies (lithofacies) as well as contacts between them were studied. Lithofacies have been labelled using Miall $(1978,1985)$ codes with some modifications (Zieliński and PisarskaJamroży, 2012; Table 1), in terms of both lithology and origin (architectural elements method). Lithofacies of similar textural and structural features were grouped into lithofacies associations, i.e. packages that originated in specified sedimentary subenvironments. Orientation (dip and dip direction) of erosional surfaces, beds and cross-laminae was measured to estimate palaeochannel morphology and flow direction. Bed inclination was identified with the local sedimentary surface (bar slope) and direction of cross-lamination dip - with current orientation. Ductile and brittle deformations were noted and measured in terms of their dimensions and orientation.

Seventy-five samples were collected from representative lithofacies. They were subjected to grain-size laboratory analyses by sieving (for sands and gravelly sands) as well as by laser diffraction (for silts). Next, the textural parameters by Folk and Ward (1957) were estimated. The samples were examined by the Passega (1964) method in order to interpret depositional mode. The analysis of frosting and rounding of quartz grains by Cailleux's method, modified by Mycielska-Dowgiałło and Woronko (1998), was also applied. The following grain groups have been distinguished: round with shiny surface (EL), round with matt surface (RM), intermediate with shiny surface $(E M / E L)$, intermediate with matt surface (EM/RM), angular with fresh surface (NU), broken grains (C). Roundness of sand grains is characterized by Krumbein (1941) grades.

$\mathrm{T} a \mathrm{ble} 1$

Lithofacies code symbols used in this study

\begin{tabular}{|l|c|}
\hline Code & Description \\
\hline T & silt \\
\hline TS & sandy silt \\
\hline ST & sand sand \\
\hline S & gravelly sand \\
\hline SG & diamictic sand \\
\hline SD & gravel \\
\hline G & sandy gravel \\
\hline GS & diamictic gravel \\
\hline GD & diamicton (till) \\
\hline $\mathrm{D}$ & Structure \\
\hline \multicolumn{2}{|c|}{ massive } \\
\hline $\mathrm{m}$ & horizontal lamination/stratification \\
\hline $\mathrm{h}$ & low-angle inclined bedding \\
\hline $\mathrm{i}$ & ripple cross-lamination \\
\hline $\mathrm{r}$ & flaser lamination \\
\hline $\mathrm{f}$ & wavy lamination \\
\hline $\mathrm{W}$ & trough cross-stratification \\
\hline $\mathrm{t}$ & low-angle cross-stratification \\
\hline $\mathrm{I}$ & deformed \\
\hline $\mathrm{x}$ & cross lamination/stratification (in general) \\
\hline $\mathrm{e}$ & erosional scour fill \\
\hline $\mathrm{d}$ & \\
\hline
\end{tabular}

\section{SEDIMENTARY SUCCESSION - DESCRIPTION AND INTERPRETATION}

The Samica I site represents the oldest and coarsest-grained unit A, Samica II and III represent a younger, sandy unit $B$, and the uppermost, diamictic unit $C$ was studied at the Samica II site (see Fig. 2)

UNIT A

Fine-grained sands with sandy-gravelly intrabeds prevail. Sands are characterized by a predominance of well- and moderately rounded grains with shiny surfaces EL+EM/EL ( $57 \%$ on average, with a predominance of EM/EL grains), i.e. typical of water current transport. There also is a high frequency of angular grains NU (average $=12 \%$ ) in comparison with other deposits of the succession studied. This fact suggests that the ice sheet was the source of these grains. A prevalence of poorly rounded grains within the $E L+E M / E L$ group, as well as a substantial contribution of the NU group indicate short transport of sands. All these features indicate the glaciofluvial origin of these deposits (cf. Goździk, 2001; Błaszkiewicz et al., 2004; Woronko, 2012).

Trough cross-stratified sets are the most common beds. The largest troughs, deeper than $1 \mathrm{~m}$ and longer than $10 \mathrm{~m}$, are filled with sand (lithofacies Se) or rarely with sandy gravel (GSe). Reactivation surfaces are characteristic features here. The large troughs contain a compound infill: sandy-clayey (diamictic) gravel with massive structure (GDm) at the base and cross-stratified gravelly sand (SGt) at the top. The succession from low-angle cross-stratified sand (SI) to horizontally stratified sand (Sh) has also been found within large troughs. Smaller trough cross-sets up to $0.5 \mathrm{~m}$ thick are sandy (lithofacies St), subordinately sandy-gravelly (SGt). Beds of massive sand $(\mathrm{Sm})$ and gravel $(\mathrm{Gm}), 40-50 \mathrm{~cm}$ thick, are a secondary lithofacies. Within the upper part of the succession an ice-wedge cast $70 \mathrm{~cm}$ long has been found.

The trough cross-stratified sets St $<0.5 \mathrm{~m}$ are linked with processes of local erosion and deposition in separation zones located distally to $3 \mathrm{D}$ dunes. On the other hand, the large troughs are interpreted to record pools in the central areas of high-energy channels (Siegenthaler and Huggenberger, 1993; Marren et al., 2009). Reactivation surfaces indicate frequent, short-term pulses of meltwater discharge. Co-existing SI and Sh lithofacies within large scours indicate the deposition from transitional and supercritical currents, which were generated by high flow velocity. Diamictic gravels, at the base of some compound infills, provide the basis for our interpretation that dramatic ablation floods (erosion of pools) were connected with glacial mass flows, which underwent initial fluvial redeposition (deposition of GDm lithofacies; Pisarska-Jamroży and Zieliński, 2014). This lithofacies provides evidence of the proximity of the ice sheet margin (cf. Aitken, 1998). The beds of massive sand $\mathrm{Sm}$ and gravel GSm are the result of abrupt aggradation. Directional data of cross-beds show that proglacial meltwaters flowed towards the SSW (mean azimuth $=218^{\circ}$ ). Palaeocurrent distribution covers $180^{\circ}$ with three main modes (towards the SSW, SSE and WSW), which probably reflect orientation of channels within the braided system.

To conclude, we interpret the succession described as the sedimentary record of a valley sandur - elongated outwash which was confined by valley slopes. It derived from the retreat of the ice sheet which formed the surrounding till plain. Rapid lateral shifting as well as extensive aggradation of braided channels were inhibited in this confined fluvial environment. 
Therefore the channel bed was frequently eroded, and abundant scours were formed. Sediments underwent repeated redeposition, which explains why the majority of the lithofacies are relatively fine grained and well-sorted.

UNIT B

These deposits are represented by fine- and medium-grained sands interbedded with silty sand. Coarse-grained gravelly sand is a fairly rare component. Thick silty beds have also been noted locally. All deposits fill the palaeochannels within the channel belt; the storeys are up to $8 \mathrm{~m}$ thick and at least $70 \mathrm{~m}$ wide (Fig. 4A, C). Peat and gyttja intervals, up to a few metres thick, are superimposed as the youngest parts of palaeochannel infills (Fig. 2B).

Sands are characterized by a distinct predominance of rounded grains with shiny surfaces (65\% on average), i.e. transported in a fluvial environment. Moderately rounded grains EM/EL prevail within this group. A high percentage of grains with intermediate, shiny surfaces may be the result of relatively short fluvial transport or, more likely, of fluvially resedimented glaciofluvial material. Similar patterns of EM/EL and EL grain percentages have been obtained from an analogue fluvial Holsteinian setting in central and northeastern Poland (Woronko, 2012).
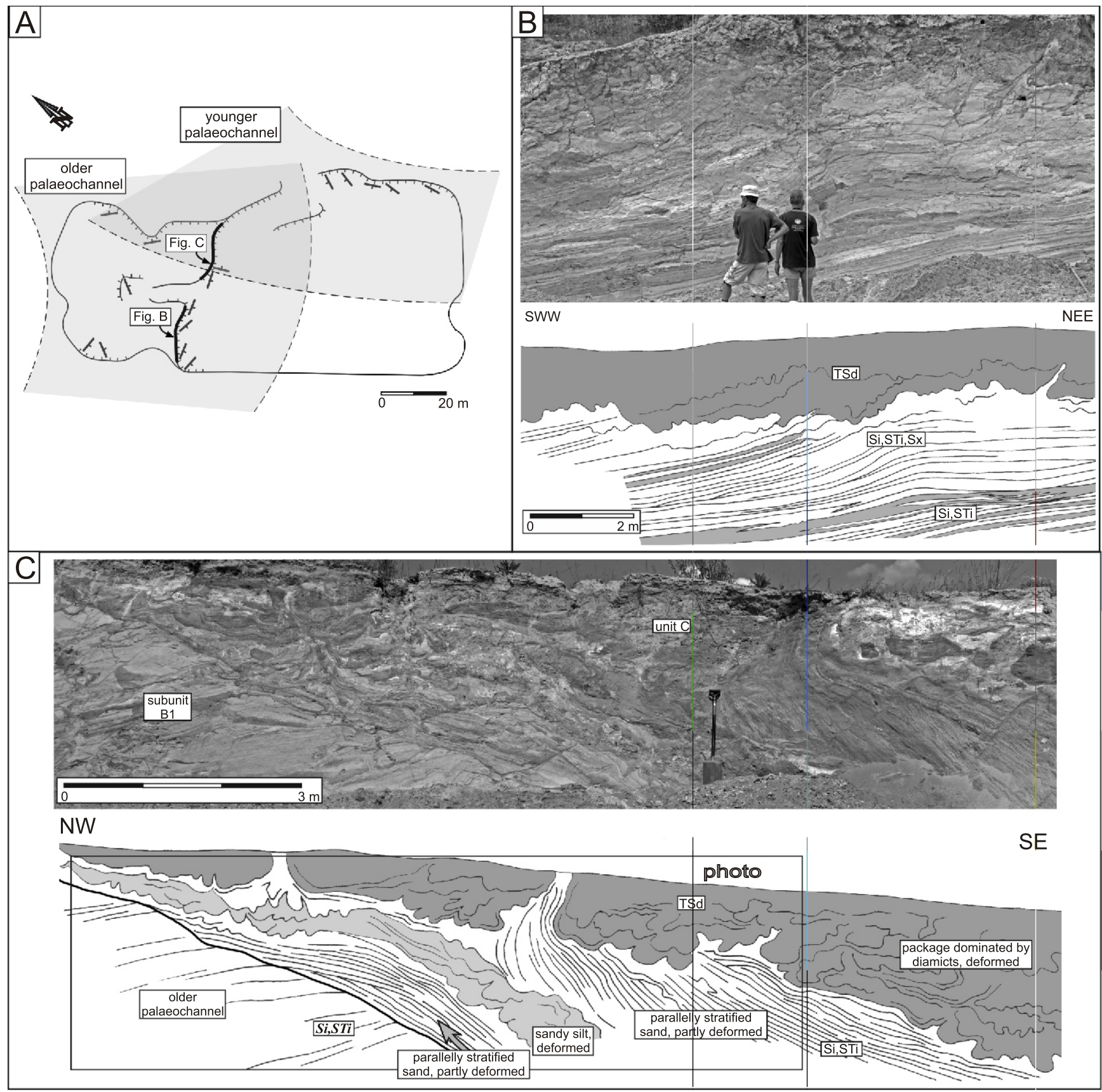

Fig. 4. The Samica II site

A - subunit B1, palaeochannel courses relative to the excavation, strike and dip of fluvial beds are marked, location of photos is also indicated; B - sandy and sandy-silty beds of a point bar (subunit B1), note the rhythmic arrangement of layers and low-angle inclination of bedding (aggrading point-bar platform), the uppermost package of deformed sandy silt is derived from channel abandonment; $\mathbf{C}$ - the younger palaeochannel is incised into point-bar deposits of the older one (subunit B1), the sandy channel facies is deformed by diamictic mass-flow loading of unit $\mathrm{C}$ 
In the light of lithological features the deposits have been divided into two subunits: B1 and B2.

SUBUNIT B1

The lithofacies of this subunit are the most fine-grained: fine sand predominates together with silty sand, while medium-grained sand comprises a few beds. The dip of beds is usually up to $20^{\circ}$ (Fig. 4B). The most common structure, both in sand and silty sand, is parallel lamination, concordant to basal surfaces of beds, i.e. it is also low-angle inclined (lithofacies $\mathrm{Si}$, $\mathrm{STi})$. These two lithofacies comprise approximately $50 \%$ of the sections studied. The sandy lithofacies $\mathrm{Si}$ forms two types of beds. The first one is relatively thick $(0.5-1.0 \mathrm{~m})$, commonly with a fining-upwards texture (from medium- to fine-grained sand). Other $\mathrm{Si}$ beds are thin (up to $20 \mathrm{~cm}$ ), tabular, usually sandwiched with silty-sandy STi lithofacies of the same or lesser thickness. Repeated alternations of these lithofacies make up rhythmite packages thicker than $1 \mathrm{~m}$ (Fig. 5). A fining-upwards tendency has been noted in the thickest rhythmite packages. The fine-grained texture of sand beds, together with their very good sorting, results in cryptic lamination. This is why some Si lithofacies pass (both horizontally and vertically) into
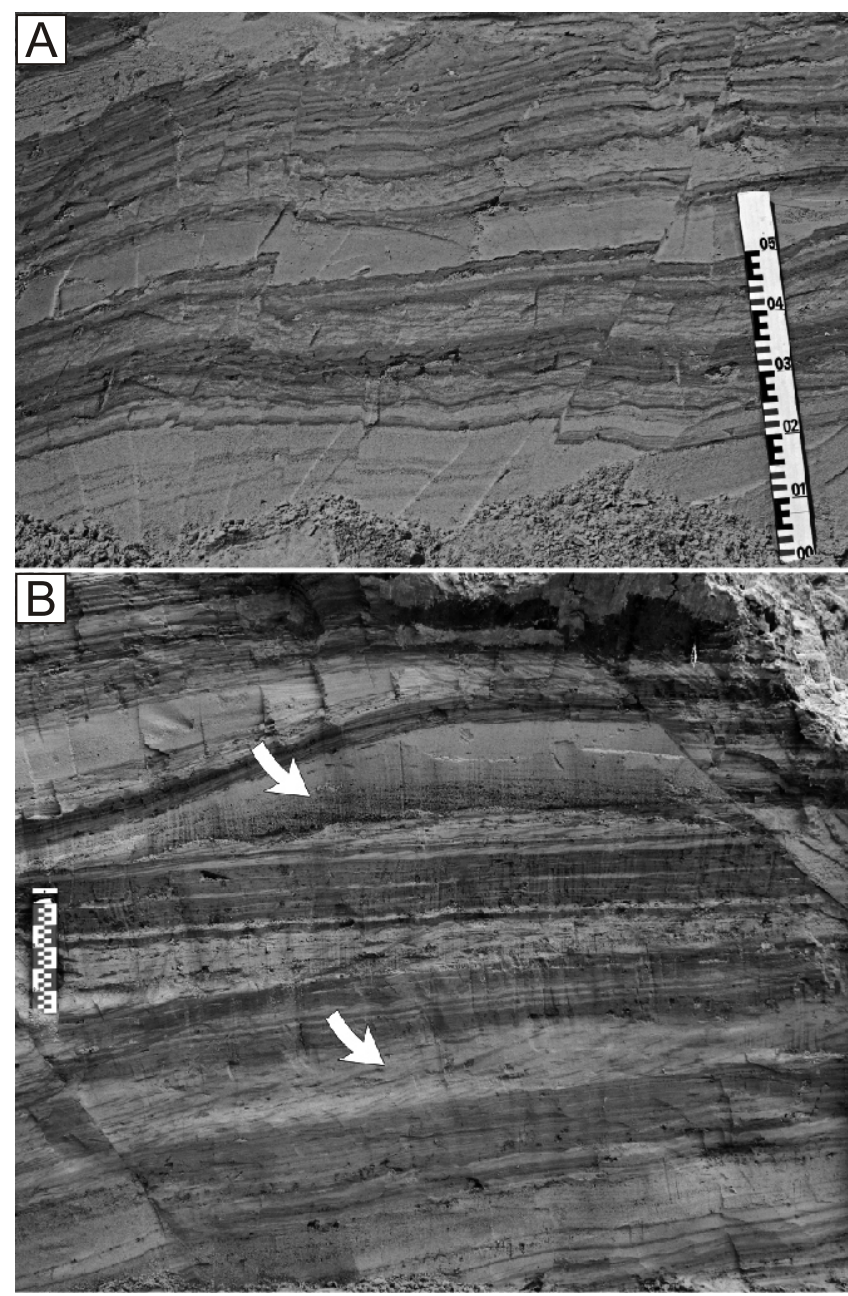

Fig. 5. Rhythmic arrangement of sand and sandy-silt layers in the point-bar facies (subunit B1)

Each sand-silt couplet was deposited during one flood; in some sand layers the fossil climbing ripples and dunes are visible

(see arrows on B)
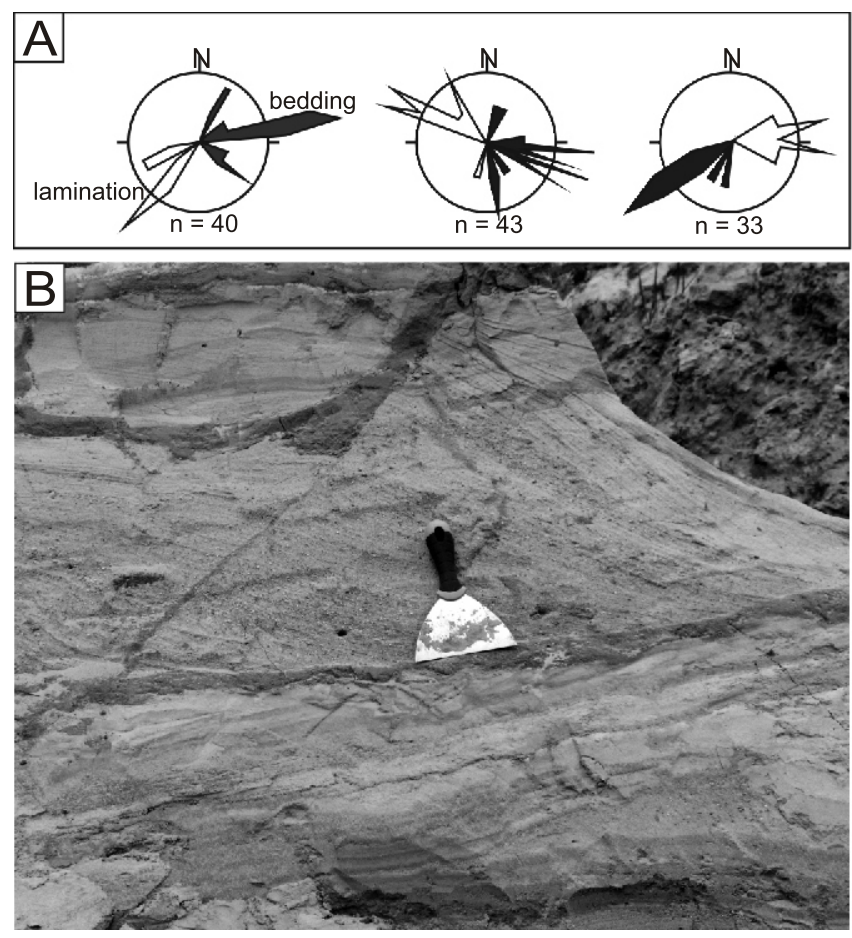

Fig. 6. Epsilon cross-stratification in the point-bar facies (subunit B1, site Samica II)

A - the diagrams show that cross-lamination dips in the opposite direction to the bedding; $\mathbf{B}$ - cross-stratified bed records the dune travelling upslope the point-bar platform

massive sand $\mathrm{Sm}$. Other lithofacies are very subordinate; none of them is more frequent than $5 \%$. They are: medium-grained sand of trough cross-stratification St (sets $20-30 \mathrm{~cm}$ thick, cosets thinner than $1 \mathrm{~m}$ ), medium-grained sand of tabular cross-stratification $\mathrm{Sp}$, fine-grained sand and silty sand with ripple cross-lamination or Sr, STr (in cosets up to $0.4 \mathrm{~m}$ ).

The morphometry of channel-derived storeys (width/depth ratio $\approx 10$ ) is comparable with that of other meandering rivers (Kraus and Gwinn, 1997; Hornung and Aigner, 1999). The low-angle inclination of beds within palaeochannels suggests that their origin was associated with side bars in a sand-bed, sinuous river. The rhythmic arrangement of numerous, thin sandy and silty lithofacies points to frequent, yet moderate, floods. Deposition took place on slightly sloping surfaces of point bars. The key evidence for this interpretation is the bimodal distribution of directional data. The modes of dip direction of beds and their internal cross-stratification are nearly opposite (Fig. 6). The first directional mode represents the slope of the bar and the second one - secondary bedforms (parasitic $2 \mathrm{D}$ dunes and ripples) which migrated upslope the bar due to transverse currents generated by meander curvature. In this context these intervals can be regarded as epsilon cross-stratification ECS (sensu Allen, 1963) or inclined heterolithic stratification IHS (sensu Thomas et al., 1987). Fully developed point-bar succession starts from a clear erosional surface (channel bottom) covered by sandy coset of trough cross-stratification St (Figs. 7 and 8D) - the sedimentary record of a thalweg zone with 3D dunes derived from deep and fast flow. The St division is succeeded by sandy-silty rhythmites $\mathrm{Si}$ and $\mathrm{STi}$ - the deposit of a point-bar platform. The lateral migration of the meander resulted in a gradual decrease of current energy over the platform; the upper part of the rhythmite division represents a subenvironment which was increasingly more distal to 


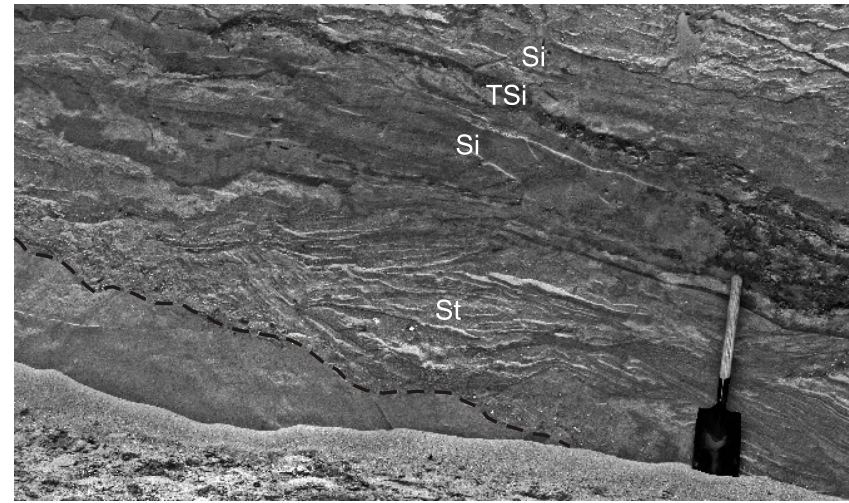

Fig. 7. The point-bar succession starts from the St coset the record of 3D dunes migrating in the thalweg zone

The upper inclined beds of sand (Si) and sandy silt (TSi) were formed on the bar slope; the base of the palaeochannel is marked by a dotted line

the thalweg zone. Such sandy-silty rhythmites are regarded as typical deposits of point bars formed in low-energy, sinuous channels (Edwards et al., 1983; Smith, 1987; Zieliński and Goździk, 2001; Mack et al., 2003; Makaske and Weerts, 2005). This process is clearly indicated by the decreasing thickness of sand beds and, concomitantly, an increasing thickness of silty-sand beds towards the top of the succession. Similar successions have been regarded as classic sedimentary records of point bars (Edwards et al., 1983; Gibling and Rust, 1993; Shukla and Singh, 2004; Uhrin and Sztanó, 2007; Vandenberghe, 2008). Local troughs that cut into the point-bar deposits (Fig. 8C) can be interpreted as chutes that dissected bar platforms (Bridge and Gordon, 1985; Evans, 1991). Finally, the point-bar facies is covered by silt (Fig. 8A), laid down under quiet conditions, where the channel was abandoned after meander cut-off. The fining-upwards trend of packages deserves attention because it is a characteristic feature of meandering river deposits (Gibling and Rust, 1993; Miall, 1996; Labrecque et al., 2011; Janssens et al., 2012; Cordier et al., 2014).

SUBUNIT B2

The beds are either in a slightly inclined position (concordant with the palaeochannel bottom in its marginal parts) or horizontal (in central parts of the palaeochannel). The textural character of this facies is quite similar to the previous one; fineand medium-grained sands co-occur with silty sand and silt. Sand and silty sand with horizontal stratification Sh, STh and massive sand Sm prevail. Laminated silt Th and sand with trough cross-stratification St play a secondary role. Massive sand with granules SGm has been rarely noted in some sections. As a rule, the lowermost division within a palaeochanne infill is a coset of St lithofacies. It is overlain by the middle division - a rhythmite of sand and silty sand beds, most often with horizontal lamination Sh and STh. The thickness of sandy-silty couplets exceeds that of the point-bar facies; it attains up to $40 \mathrm{~cm}$. The uppermost part of palaeochannel infills is of fine-grained character. Laminated sandy silt TSh or silt Th predominate. Infrequent lenticular intercalations of fine sand are not thicker than $10 \mathrm{~cm}$. Most often this part of the succession is deformed in load-cast structures. A fining-upwards tendency is noted in individual lithofacies associations as well as in the overall succession.
Sedimentation in slightly sinuous channel segments between successive meanders depends mainly on vertical accretion. Nearly all lithofacies (except St) are typical of this kind of deposition. In this way abundant shoals - riffles - were formed. Shallow currents, faster and wider than in meanders, were characterized by conditions of the upper part of the lower flow regime, which is consistent with the origin of the Sh and SGm lithofacies. The presence of the Sh lithofacies can be treated as contradicting the meander zone (Allen, 1970). The infrequent occurrence of the St lithofacies suggests that the deeper parts of the channel (the pools), covered by 3D dunes, were quite local here. The regular vertical transition of three divisions (St $\Rightarrow$ Sh \& STh $\Rightarrow$ Th) into the $5 \mathrm{~m}$ thick fining-upwards succession, allows us to compare the sedimentary profiles studied to ancient meandering rivers (Stewart, 1981; Gardner, 1983).

In summary, the mixed-load river (sensu Schumm, 1971) was the sedimentary environment of unit B. Deposition from low-energy saltation and fine-grained $(<0.1 \mathrm{~mm})$ suspension (Fig. 9) prevailed. Architectural elements of the succession also point to a low-energy fluvial environment, as indicated by the low frequency $(6 \%)$ of the St lithofacies, which is a typical record of extensive channel flow. The Samica fluvial succession reveals numerous similarities to the sixth lithotype in Miall's (1985) classification, i.e. a typical sand-bed meandering river with well-developed point bars.

UNIT C

The uppermost palaeochannel infills at the Samica II site are overlain by and laterally pass into $2 \mathrm{~m}$ thick diamictic package of lenticular shape locally (Figs. 4C and 8B, C). The irregular, deformed beds of clayey sand with a granule admixture (SDd) alternate with discontinuous sand layers of crude stratification and rare lenses of diamictic breccia. Load casts and slightly asymmetrical flow casts (up to $1.5 \mathrm{~m}$ in amplitude) as well as inclined decimeter-scale drag and flow folds are the most abundant soft-sediment deformations (Fig. 4C). Flow casts and flow folds converge towards the $E$ and SE, which is consistent with the dip direction of the basal surface of the package. In addition, subvertical, up to $20 \mathrm{~cm}$ wide, extensional fractures are injected with the underlying fluvial sands (Fig. 10). Soft-sediment deformation structures indicate that the diamictic package was likely to be deformed predominantly by ductile simple shear driven by gravity flow. Extensional fracturing probably developed during increases of strain rate and pore-pressure. Both factors can be readily controlled by an abrupt overloading of extensively aggrading soft surficial material. We interpret that the dense, cohesive debris flows moved from the adjacent till plain towards the valley. This is supported by gravel fabric distribution; the main mode is oriented in a $94^{\circ}$ azimuth, i.e. transverse to the fossil valley axis. Brief events of slope wash formed thin, discontinuous sand layers sandwiched between diamicts. Ductile deformation of underlying fluvial sands and their evolution into fracture structures indicate that mass flow phenomena originated not long after fluvial deposition; the alluvium was still waterlogged. Distinctive results have also been obtained from grain morphology analysis. The deposit is characterized by the highest frequency of aeolian reworked grains $(\mathrm{RM} \& \mathrm{EM} / \mathrm{RM}=75 \%)$, as well as the lowest content of fluvially reworked grains ( $E L \& E M / E L=15 \%$; Fig. 11). This feature seems to be an important palaeoclimatic indicator. The gelifluction redeposition had to be active synchronically with aeolian supply, i.e. under the conditions of discontinuous permafrost (see Van Steijn et al., 1995). It is characteristic that defor- 


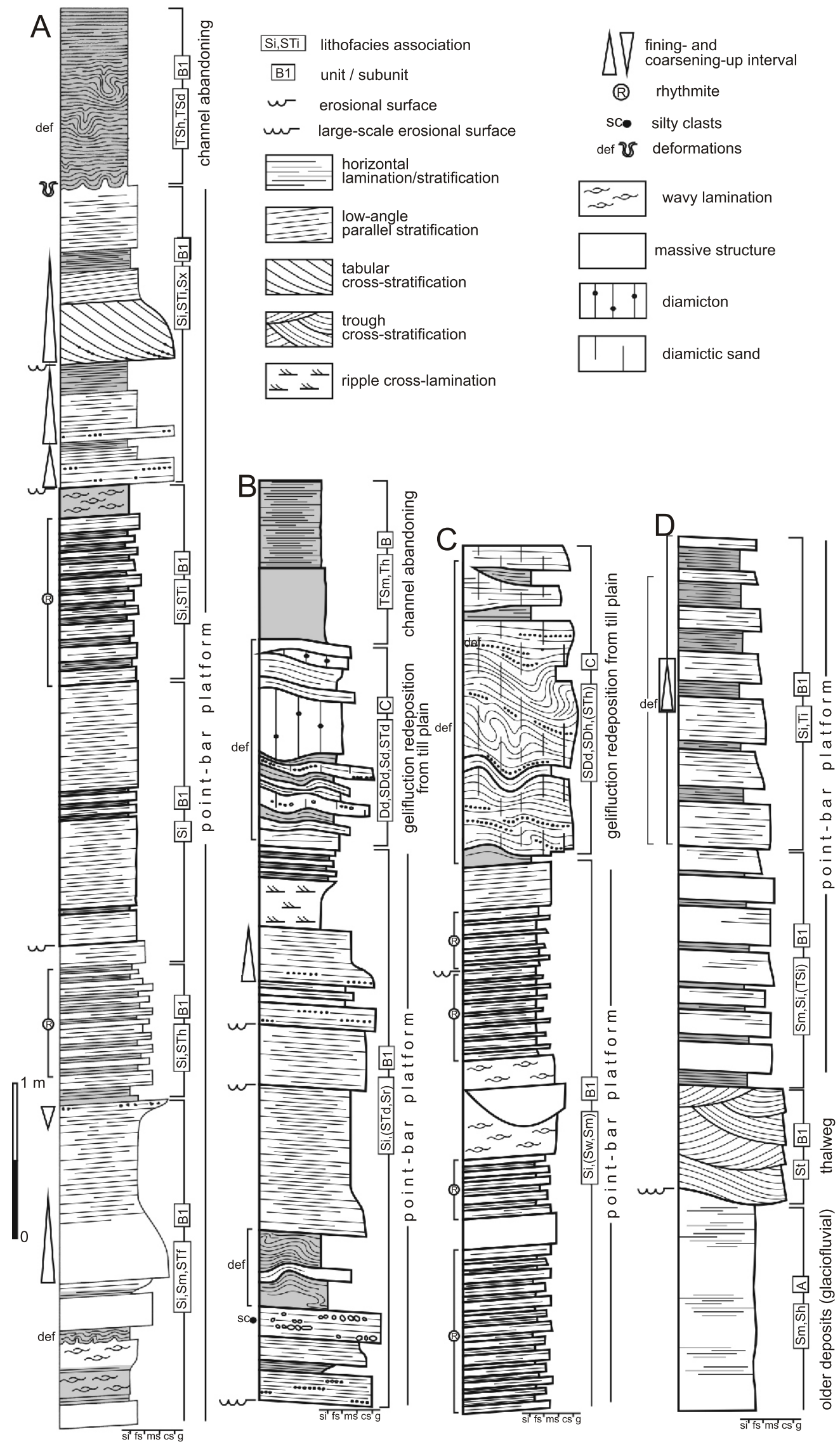

Fig. 8. Sedimentary logs of palaeochannel infills

A - the Samica II pit, older palaeochannel; B - the Samica II pit, younger palaeochannel (western part); C - the Samica II pit, younger palaeochannel (eastern part); D - the Samica III pit 


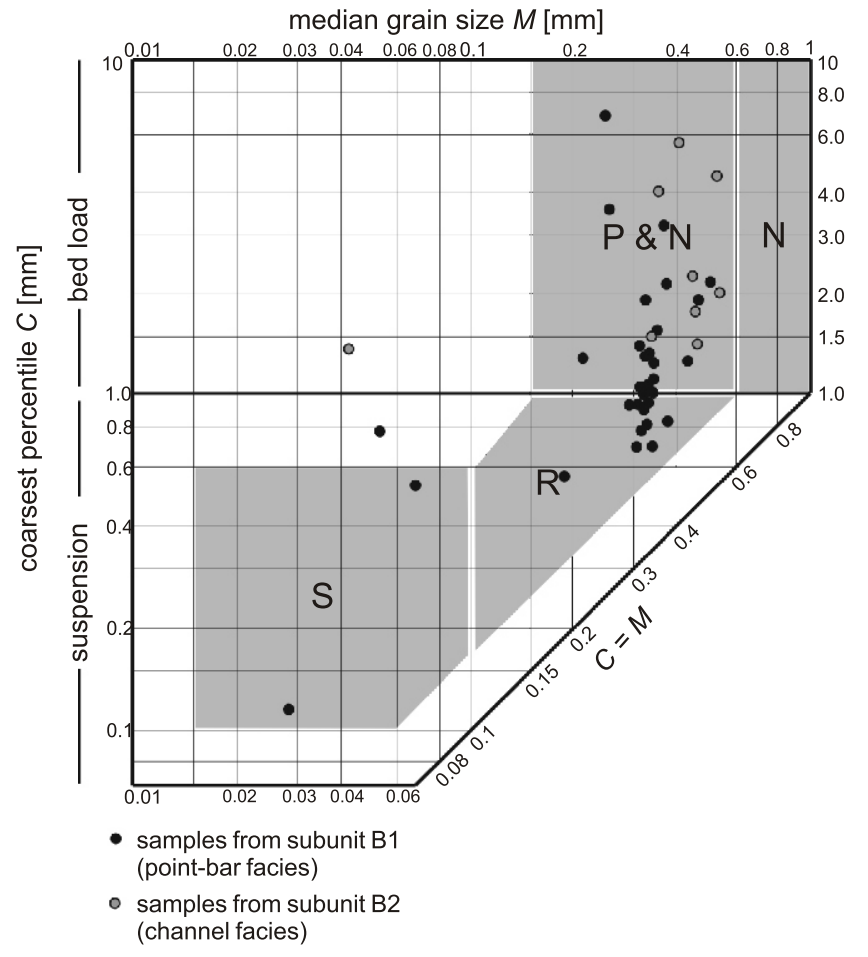

Fig. 9. Passega graph of fluvial deposits

Note that the samples from the channel facies (subunit B2) are slightly coarser and represent deposition from saltation, whereas the deposits of the point-bar facies (subunit B1) were derived from suspension and low-energy saltation; $\mathrm{N}$ - rolling, $\mathrm{P} \& \mathrm{~N}$ - saltation and rolling, $\mathrm{R}-$ mainly graded suspension, $\mathrm{S}-$ mainly homogeneous suspension

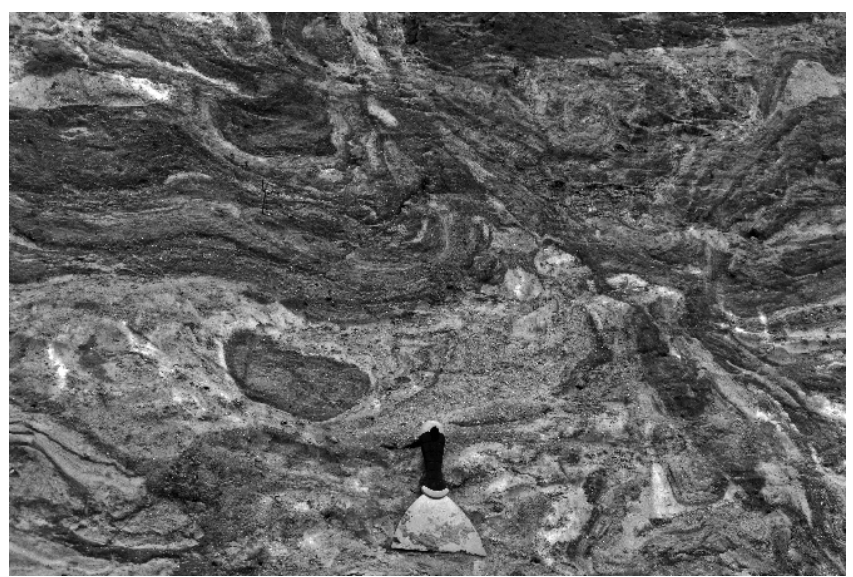

Fig. 10. Marginal part of the younger palaeochannel in the Samica II site

Diamictic gelifluction lobe (unit C) deformed the underlying channel sands (unit B) which protruded upwards through the hydrofracture
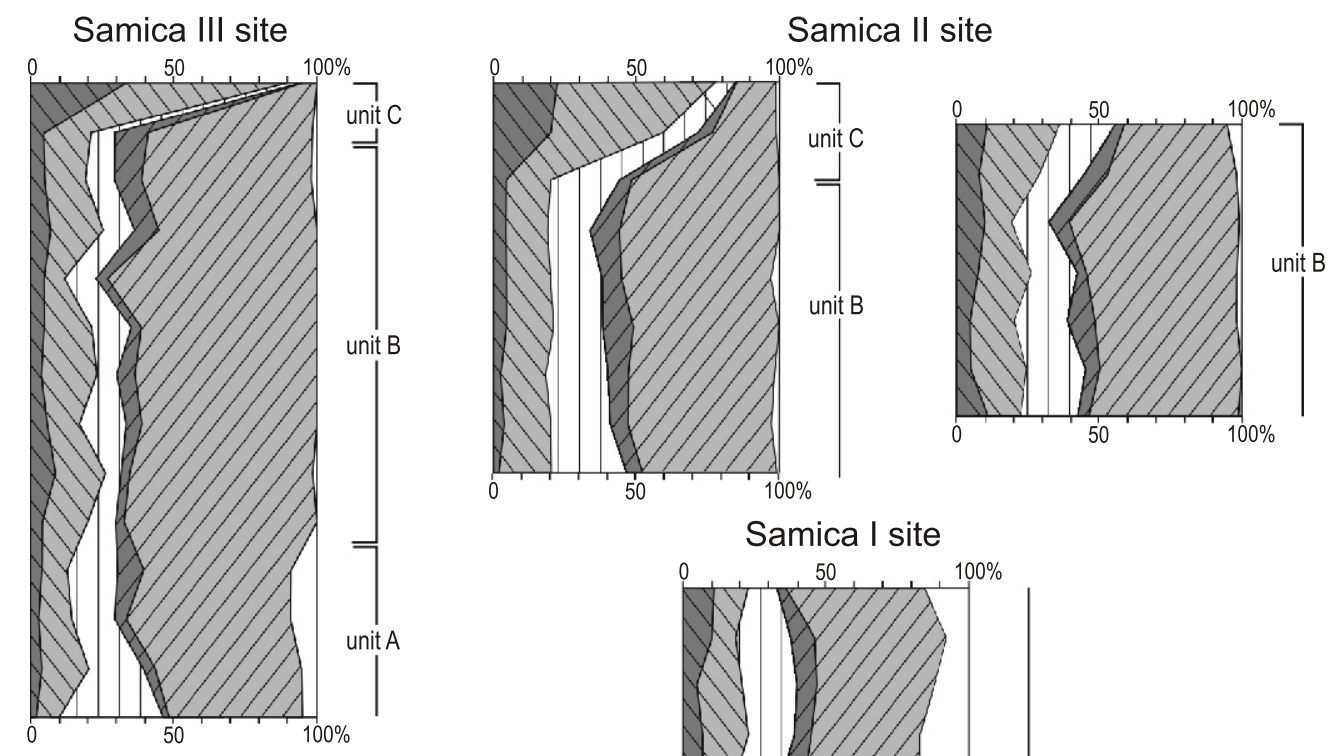

Samica I site

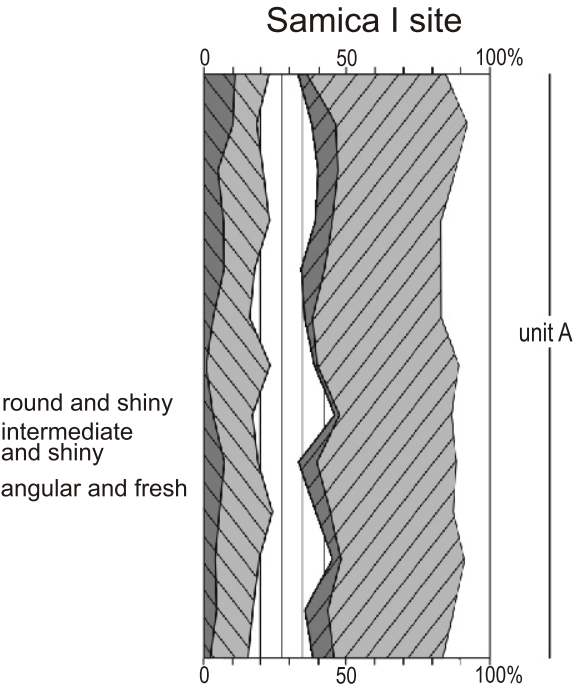

Fig. 11. Variability of morphoscopic features of quartz sand grains in the sedimentary succession of the Samica valley 
mation structures analogous to the ones described above have also been noted in the same stratigraphic position in other palaeochannel infills (Figs. 4B and 8).

\section{DISCUSSION}

\section{THE CHANGE FROM A "COLD” BRAIDED OUTWASH SYSTEM} TO A "WARM" MEANDERING RIVER

The presence of flowtill remnants within the glaciofluvial succession (unit $A$ ) indicates that the older succession can be seen to record cold climatic conditions. It is well known that cold-stage fluvial systems usually develop a braided channel pattern. Very high sediment supply, exceptional unsteadiness of discharge, short-term cyclicity of sediment and water delivery, are all features that indicate that sedimentation occurred in numerous, wide and shallow sand-bed channels. On the other hand, pollen and plant macrofossil analyses of the organic infill of the Samica palaeomeander point to a warm and wet climate, typical of an interglacial (Pidek et al., 2014). Geochronological dating (412-445 ka) indicate that the meandering pattern of the river is attributable to the interval spanning the latest Elsterian and the earliest Holsteinian (Terpiłowski et al., 2014). Therefore, in the Samica valley two waterlain successions illustrating quite different palaeoenvironmental conditions formed in succession: a cold braided outwash (unit $A$ ) was followed by a meandering river (unit B) associated with a temperate climate. Both successions differ distinctly in lithology as well as in depositional forms and processes (Fig. 12).

The basic question now arises: what was the reason for the change from a braided to a meandering pattern? We must take into account that an organic succession forms the upper infill of the younger palaeochannel excavated. Pollen analysis has shown that it starts from a boreal forest phase, followed by warmer, climatic optimum ones. This means that a well-developed meandering river was already present in the Samica valley during the onset of the interglacial. Therefore the change of river pattern to a meandering one cannot be placed stratigraphically in an advanced phase of the interglacial and interpreted as a result of a really warm climate. In our opinion two important factors need to be considered.

The first factor recognized is river discharge and regime. It is broadly known that large and frequent floods are typical of a braided fluvial pattern and a decrease of floods leads to a change to a meandering pattern (see, among others, Schumm and Lichty, 1963; Falkowski 1982; Nanson et al., 1988; Jersak et al., 1992). Cyclic, flashy ablation floods (even of catastrophic character) are a typical feature of the proglacial zone. In our opinion the change from braided to meandering in the Samica River resulted mainly from a steadier hydrological regime (i.e. lower variations in discharge). The most-probable explanation for this was the disappearance of meltwater discharge during the decay of the ice sheet. When the ice sheet margin retreated to the north, the hydrological regime in the valley studied changed from glacial to nival and then, in the latest Elsterian, to a pluvial-nival one. During the last of these phases the winter seasons shortened and fewer snow masses melted, which resulted in lower discharges of spring floods. The intensity of summer floods was related to the degree of climate continentality. Most probably in the glacial-interglacial transition continental features were expressed (with extensive spring floods), whereas during the first half of the interglacial the climate became increasingly more temperate and the role of floods diminished (cf. Van Huissteden, 1990; Sidorchuk et al., 2001; Vandenberghe, 2001; Erkens et al., 2009).

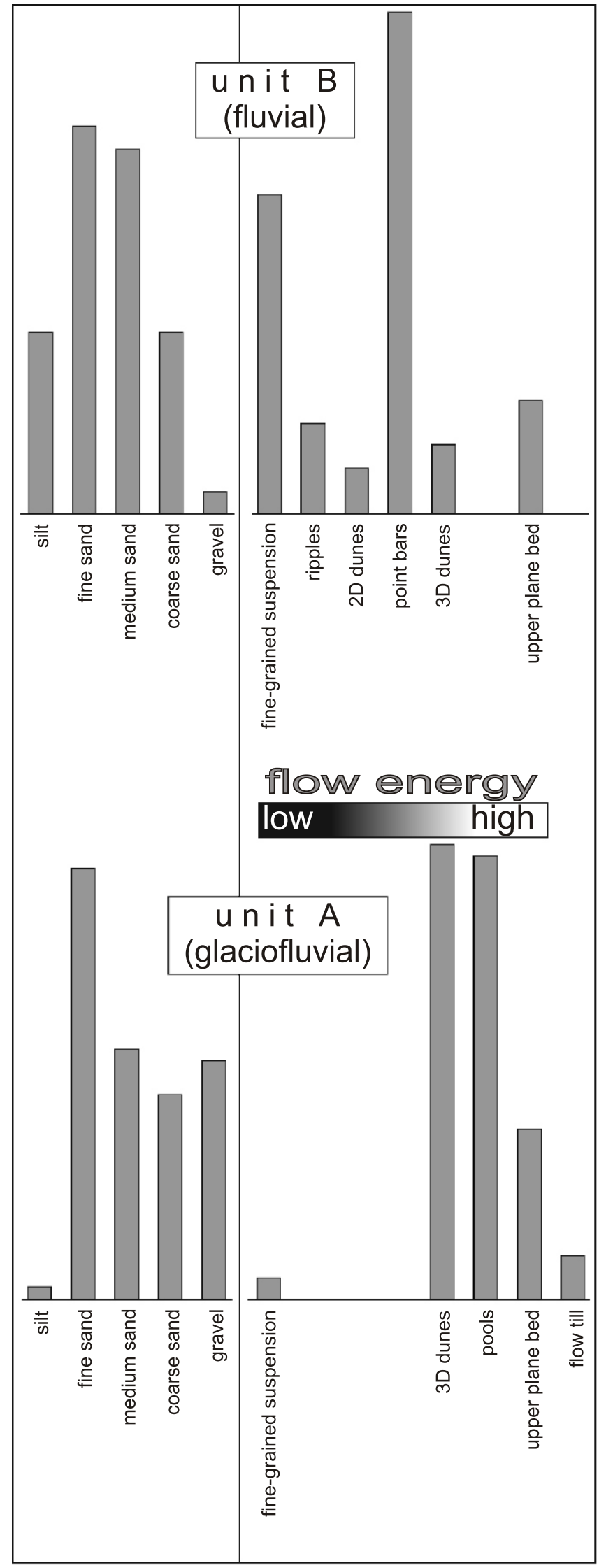

Fig. 12. Fluvial (unit $B$ ) and glaciofluvial (unit A) deposits in the context of grain size and architectural elements 
The second factor is associated with sediment discharge, especially bedload. Deposits constituting the braided channels are coarser than the younger meandering river alluvium, especially in the coarse sand and gravel grain-size ranges (Fig. 12). It is clear to the authors that the outwash flows were represented by a higher concentration of coarse-grained bedload. It is assumed that a reduction of bedload concentration and its finer character are important agents that controlled braided-to-meandering fluvial evolution (Maizels, 1983; Teisseyre, 1991; Erkens et al., 2009; Metivier and Barrier, 2012). In our opinion such conditions were readily achieved when abundant supply of coarse material stopped due to ice sheet retreat. From this time the Samica fluvial system redeposited the valley deposits. Moreover, vegetation cover appeared as a result of climate amelioration; first it was tundra, then patchy local boreal forest. The vegetation factor led to a decrease of sediment supply by rainwash to the alluvial channel. The hydrological regime evidently became steadier and surface wash events were less intensive. As a result, the grain size of washed-out sediments reaching the river channel was also diminished.

Studies of the Late Glacial (MIS 5d-2) fluvial evolution show that complete braided-to-meandering river transitions were relatively slow (Huisink, 1997; Gao et al., 2007; Erkens et al., 2009). On the other hand, Ferguson (1987) and Sarma (2005) suggest that a change of river pattern has a relatively short duration, even in the range of decades. In our opinion the Samica River changed its pattern rapidly, because the environmental impulse - the retreat of nearby ice masses - was exceptionally strong. All other agents were forced by climatic changes which occurred more slowly and less extensively. From this reason the river likely became meandering within the late Elsterian. This is corroborated by the fact that the organic succession, following point-bar development, represents the initial boreal part of the Holsteinian (Pidek et al., 2014).

\section{EROSION AND AGGRADATION PHASES DURING} THE GLACIAL-INTERGLACIAL CLIMATIC CYCLE

The Elsterian ice sheet covered the area studied completely. It had the largest thickness of all Pleistocene ice sheets in Poland, and reached farthest south. In front of the retreating ice sheet the outwash, confined by a valley, developed in a north-south orientation. The braided river system accumulated glaciofluvial deposits up to $20 \mathrm{~m}$ thick. Simultaneous with the retreating ice sheet margin, the aggradation ratio, coupled with the braiding index (number of active channels in the valley transect), decreased and the braided system started to evolve towards a single-channel, sinuous pattern. This process had to be associated with intense erosion. Immediately after deglaciation, in the vicinity of the ice sheet, incision is stronger than in normal European rivers from younger glacials and away from ice-limits. Together with progressive ice sheet retreat, the erosion-dominant zone moved northwards and fluvial aggradation started to prevail in the Samica valley. In consequence, the deposits of the temperate river infill a large, valley-scale incision, cut into outwash and till of Elsterian age (Fig. 2B). This large-scale incision can be identified as a regional sixth-order bounding surface in Miall's (1995) nomenclature. This erosional phase of the Samica valley development coincides with the models of Teisseyre (1991), Bridgland (1994, 2000), Bogaart and van Balen (2000), Mol et al. (2000), Vandenberghe (2002), Westaway et al. (2002), Bridgland et al. (2004), Lewis et al. (2004), Busschers et al. (2008) and Cordier et al. $(2012,2014)$, where extensive river incision is located dur- ing the cataglacial or the glacial-to-interglacial transition. In Teisseyre's (1991) opinion the erosion mentioned above was connected with the "senile" phase of a braided river (degradational braided river), just before transition to the meandering pattern. Vandenberghe (2008) proposed that the erosion controlled by the cold-to-warm climatic transition was especially deep.

Some studies confirm that the temperate climate of interglacials was more conducive to river erosion than to sedimentation (Fuller et al, 1998; Huisink, 2000; Bogaart et al., 2003). Starkel (1996) suggested that during the Holsteinian the Polish rivers were also characterized by erosion. Our study of the Samica valley sites does not corroborate this hypothesis. In our opinion, significant sedimentation in a meandering channel occurred from the end of the Elsterian to the first half of the Holsteinian (Table 2), i.e. in the 1st and 2nd interglacial fluvial phase of Gibbard and Lewin's (2002) division. Several generations of point bars (Fig. 4), together with palaeobotanical interpretation of an oxbow infill (Pidek et al., 2014), substantiate this claim. A large volume of sandy glaciofluvial deposits was available in the valley, which could be easily redeposited by a meandering river. As a result, sedimentation prevailed over incision in the interglacial valley. Our finding matches conclusions drawn by Vandenberghe et al. (1994) and Krzyszkowski (1996) that the Quaternary meandering temperate fluvial systems were aggradational ones.

Also worthy of note is that a laterally extensive overbank fine-grained (silty) facies has not been documented in the sites studied. Generally, this should be relatively common in the uppermost part of a fluvial succession (Bourquin et al., 2009). We speculate that the dense coniferous forest of the advanced part of the interglacial resulted in decreased river discharge as well as sediment supply. Reduced fluvial activity was restricted to the narrow channel zone and overbank accumulation did not then take place (see Antoine et al., 2000).

The highest part of the organic succession indicates that gradual cooling and advance of transitional climatic conditions prevailed from the Holsteinian to the Saalian (Pidek et al., 2011; Terpiłowski et al., 2014). Moreover, in the uppermost part of the youngest point-bar deposits the percentage of wind-reworked sand grains (i.e., with matt surface) increases (Fig. 11). Periglacial conditions occurred and mass flow (gelifluction) processes led to redeposition of strata, from the till plain to the marginal part of the valley. In this way the uppermost interval of the succession studied, the diamictic sands, were formed.

It is likely that fluvial erosion started to predominate in the final phase of the Holsteinian (Table 2). In a subpolar climate the Samica River was characterized by a nival regime. Extensive floods occurred during spring when thick snow covers melted. The presence of permafrost prevented water from penetrating the ground, which resulted in increased flood discharges as well as a heightened erosional potential (see Krzyszkowski, 1991; Huisink, 2000; Gibbard and Lewin, 2002). In this we see an explanation of the fact that fluvial packages above the gelifluction interval are missing. In Vanderberghe's (2008) opinion erosion at interglacial-to-glacial transitions was relatively shallow, but across wide areas in valleys.

COMPARISON OF THE SAMICA SUCCESSION WITH OTHER INTERGLACIAL FLUVIAL RECORDS

It is still difficult to compare fluvial sedimentary successions across Europe. Detailed sedimentological analyses of interglacial (excluding the Holocene) alluvia are very few. For example, in southern Poland and the northern Czech Republic some ter- 
Sedimentation history of the valley studied in a glacial-interglacial cycle

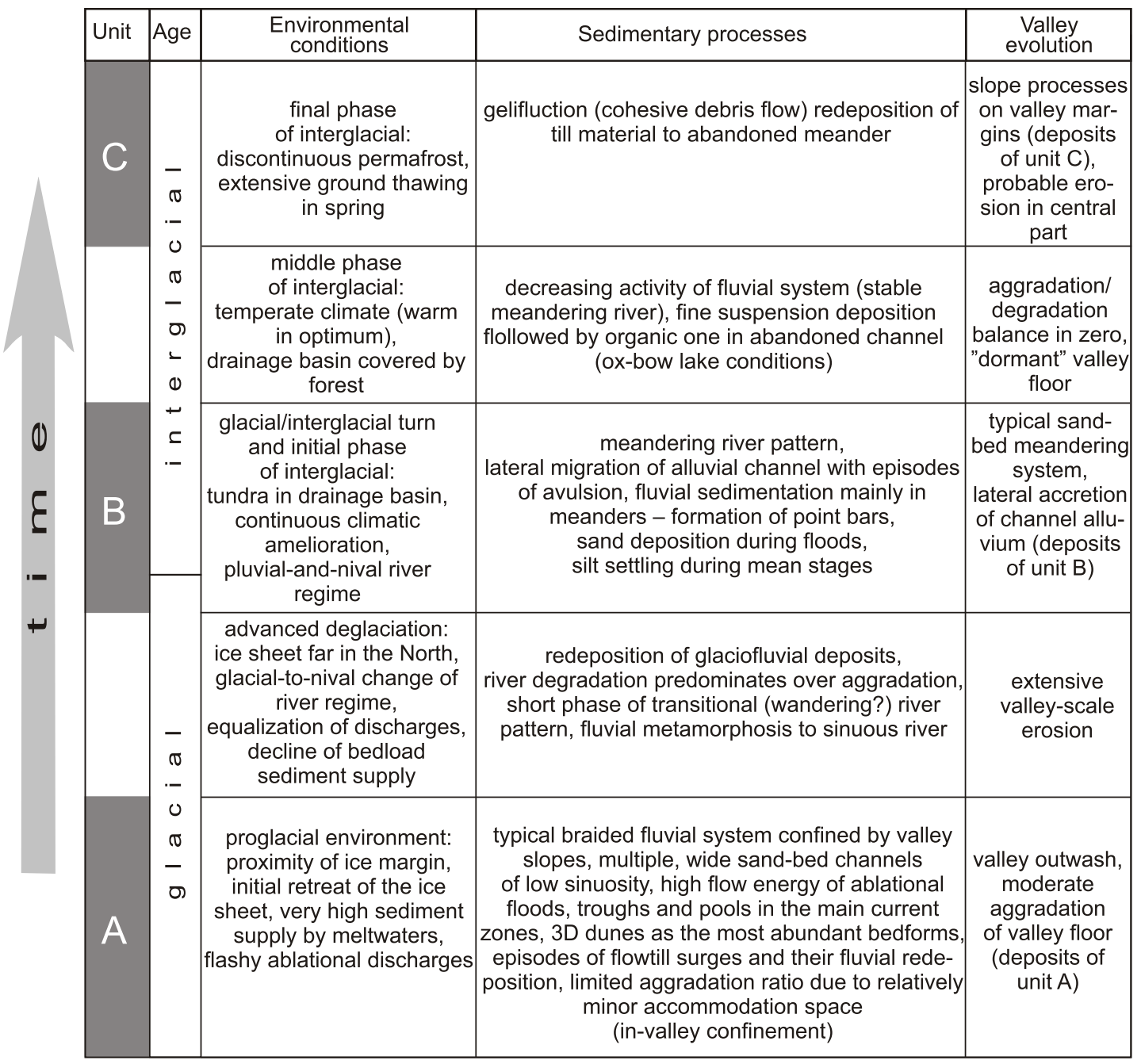

races have been interpreted to be of Holsteinian age, but their deposits have been documented only by boreholes (Lewandowski, 1988). In practice, only a few data from the British Isles can be taken into account. The most universal and meaningful research of Pleistocene interglacial fluvial deposits was the one conducted by Gibbard and Lewin (2002). They deduced that the scenarios of river development were the same during the warm stages of the Middle and Late Pleistocene (MIS 19/18-6 and MIS 5e-2). The basic conclusion is that in the British Islands at the time the temperate rivers of an anastomosing or stable meandering (i.e., transitional to anastomosing) channel pattern were most typical. Occurrences matching the Samica River valley (i.e., a freely meandering river, dominated by point-bar sedimentation) are few and far between in the British Isles (Bridgland et al., 1990). Anastomosing and stable meandering rivers are both characterised by very weak (or absent) lateral channel migration (Nanson and Knighton, 1996; Gibling et al., 1998; Gradziński et al., 2003; Abbado et al., 2005). They are controlled by a specific hydrological regime: frequent, but moderate in discharge floods, and consequently generally low flow velocities (Makaske, 1998; Tooth and Nanson, 1999; Blum and Tornqvist, 2000; Assine, 2005).

It is important to discuss herein why the interglacial British fluvial systems were different from the Polish ones in channel pattern (i.e., river type). In our opinion climatic conditioning was the main governing agent. It is clear that the Holsteinian climate in
Western Europe was of a more oceanic type than that in eastern Poland. Pollen records of vegetation events are highly sensitive to climate changes especially when derived from long sequences or of high resolution (Tzedakis et al., 1997; Koutsodendris et al., 2010). The following palaeobotanical premises provide a west-east continentality gradient. In England, the Holsteinian Interglacial sites, referred to as Hoxnian, have been correlated with MIS 11 and studied in detail during the last decade on account of traces of Palaeolithic settlers (Preece et al., 2007; Ashton et al., 2008). At the Marks Tey site, the source of the most complete pollen diagram from England, Turner and West (1968) documented a spread of riverine temperate elements (elm Ulmus, ash Fraxinus, oak Quercus), which predated the one in Poland, e.g. in the Betula-dominated HI pollen zone that represents the protocratic phase of the interglacial. This phase can be correlated with the transition between the Pinus-Betula-Larix and Picea-Alnus-Fraxinus-/Ulmus/ pollen zones of the Kolonia Domaszewska diagram. According to the division of the Holsteinian interglacial in Poland into regional pollen zones, as based on more than 100 sites (Krupiński, 2000), these two zones represent the regional pollen zone M2 Betula-Pinus-Picea-Alnus. Our pollen diagram exhibits fewer oceanic features of climate as seen from the distribution of larch and spruce, tree types associated with a continental climate. High percentages of Quercus and Ulmus pollen in the next (e.g., HIla) zone of the Marks Tey diagram are never reached in the Holsteinian pollen diagrams in Poland (Krupiński, 2000). Similar 
features of much higher oceanicity reflected in the spread of riverine forests with elm, oak and ash are observable in a high-resolution pollen diagram of Holsteinian dry maar deposits (500 m a.s.I.) from Döttingen in southern Germany (LPAZ 2; Diehl and Sirocko, 2007) in spite of all the differences in sedimentary environment. Thus, the spread of riverine forest communities must have been much more expressive in England and in southern Germany at the start of the Holsteinian interglacial. In Poland, at the time, many forest habitats were occupied by spruce and spruce-alder communities (regional pollen zone M3 Picea-Alnus-/Pinus/ according to Krupiński, 2000). The same conclusion on well-expressed oceanic features of climate can be derived from the successive distinct hazel Corylus expansion in England (e.g., HIlc) and in southern Germany (LPAZ 2-3). This thermophilous shrub is considered to be sensitive to humidity (Granoszewski, 2003). By contrast, in the Polish pollen diagrams of Holsteinian age, Corylus is never represented in high numbers (Krupiński, 2000). Moreover, the thermophilous creeper Hedera and the shrub Ilex occur early, coevally with high pollen values of riverine trees in such communities in England and southern Germany (Turner and West, 1986; Diehl and Sirocko, 2007), i.e., predating the Polish record.

Furthermore the presence of a marine transgression is also an essential part of the discussion of Holsteinian climate in Europe. In the western part of the continent the sea deeply penetrated into the valleys in the form of large estuaries which must have had a significant impact on climatic humidity. On the other hand, the transgression of the pre-Baltic Sea in Poland remains an unproved hypothesis (Mojski, 2005).

To summarise, it seems to us that the anastomosing or stable meandering pattern of the British rivers may have resulted from a more oceanic (humid) climate, i.e. higher annual precipitation, but lower maximum river discharges than in the eastern part of Europe. Presumably, Eastern Polish fluvial systems were formed by more flashy floods. The distribution of discharges was too unsteady for anastomosing channel patterns to develop. The rivers still meandered with extensive point-bar sedimentation, as shown by our example from the Samica valley.

\section{CONCLUSIONS}

The main sedimentary successions that formed under different climatic conditions have been studied in the Samica River valley: a glaciofluvial succession (of Elsterian age) and a fluvial succession (of the Holsteinian interglacial). These de- posits vary distinctly in textural and structural features as well as in the architecture of environmental elements.

The change from a braided to a meandering channel pattern took place prior to the end of glacial. The main governing agents of this fluvial metamorphosis were: a decrease of flow discharge (termination of meltwater supply) and equalisation of annual hydrographs (change from a nival to a pluvial-nival hydrological regime). Moreover, the reduction of bedload transport due to diminished sediment supply from the retreating ice sheet was the next important factor of river evolution to a meandering pattern.

The braided-to-meandering river transition resulted in erosional incision of the alluvial channel. This large-scale degradation of the valley floor should be stratigraphically coeval with the end of the glacial. All of the first portion of the interglacial was characterized by fluvial aggradation. More probably, erosional processes started to predominate again during the final stage of the interglacial.

Interglacial fluvial deposits derived from the environment of a typical meandering river. The sands and silty sands, together with packages of peat and gyttja, fill in palaeochannels. The most characteristic and informative facies is that of the point-bar: a rhythmite of sand and silty sand showing parallel, low-angle lamination. Fining-upwards cycles are common. The packages of epsilon cross-stratification contain cross-lamination oriented in a direction opposite to the dip of beds. They were deposited as a result of secondary currents acting upslope on to point-bar platforms.

Fluvial Holsteinian/Hoxnian deposits in the British Isles mostly represent environments of anastomosing rivers, unlike the succession studied here which is a record of a typical meandering river. We hypothesise that the contrast of river types was controlled by climatic differences between Western Europe and eastern Poland. The climate of the latter region was more continental, i.e. rainfall was more concentrated in the hydrological year and resulted in more extensive floods. Eastern European rivers were characterized by higher energy, which explains why they did not evolve into an anastomosing channel pattern.

Acknowledgements. This work has been supported financially by the Polish Ministry of Science and Higher Education project no. N N306 198739 - "Climatic cycles of Middle Pleistocene recorded in sedimentary succession in the Łuków region (E Poland)". Special thanks are extended to the reviewers: A. Wysocka and J. Rose for their expert comments. We are also indebted to J. Jagt for linguistic correction.

\section{REFERENCES}

Abbado, D., Singerland, R., Smith, N.D., 2005. Origin of anastomosis in the upper Columbia River, B.C., Canada. IAS Special Publication, 35: 3-15.

Aitken, J.F., 1998. Sedimentology of Late Devensian glaciofluvial outwash in the Don Valley, Grampian Region. Scottish Journal of Geology, 34: 97-117.

Allen, J.R.L., 1963. The classification of cross-stratified units, with notes on their origin. Sedimentology, 2: 93-114.

Allen, J.R.L., 1970. Studies in fluviatile sedimentation: a comparison of fining-upward cyclothems, with special reference to coarse-member composition and interpretation. Journal of Sedimentary Petrology, 40: 298-323.
Andres, W., Bos, J.A.A., Houben, P., Kalis, A.J., Nolte, S., Rittweger, H., Wunderlich, J., 2001. Environmental change and fluvial activity during the Younger Dryas in central Germany. Quaternary International, 79: 89-100.

Antoine, P., Latridou, J.P., Laurent, M., 2000. Long-term archives in NW France: response of the Seine and Somme rivers to tectonic movements, climatic variations and sea-level changes. Geomorphology, 33: 183-207.

Antoine, P., Maunaut, A.V., Limondin-Lozouet, N., Ponel, P., Duperon, J., Duperon, M., 2003. Response of the Selle River to climatic modifications during the Lateglacial and Early Holocene (Somme basin - N France). Quaternary Science Reviews, 22: 2061-2076. 
Ashton, N., Lewis, S.G., Parfitt, S.A., Penkman, K.E.H., Coope, G.R., 2008. New evidence for complex climate change in MIS 11 from Hoxne, Suffolk, UK. Quaternary Science Reviews, 27: 652-668.

Assine, M.L., 2005. River avulsions on the Tequari megafan, Pantanal wetland, Brazil. Geomorphology, 70: 357-371.

Blum, M.D., Törnqvist, T.E., 2000. Fluvial responses to climate and sea-level change: a review and look forward. Sedimentology, 47, Supplement, 1: 2-48.

Błaszkiewicz, M., Woronko, B., Jastrzębski, E., 2004. Development of aeolian processes in Quaternary in Starogard Lake District recorded in textural features of deposits (in Polish with English summary). Prace Geograficzne, 200: 27-45.

Bogaart, P.W., van Balen, R.T., 2000. Numerical modelling of the response of alluvial rivers to Quaternary climate change. Global and Planetary Change, 27: 147-163.

Bogaart, P.W., Tucker, G.E., de Vries, J.J., 2003. Channel network morphology and sediment dynamics under alternating periglacial and temperate regimes: a numerical simulation study. Geomorphology, 54: 257-277.

Bourquin, S., Guillocheau, F., Peron, S.,2009. Braided rivers within an arid alluvial plain (example from the Lower Triassic, W German Basin): recognition criteria and expression of stratigraphic cycles. Sedimentology, 56: 2235-2264.

Bridge, J.S., Gordon, E.A., 1985. Quantitative interpretation of ancient river systems in the Oeonta Fm., Catskill Magnafaces. GSA Special Paper, 201: 163-181.

Bridgland, D., 1994. Terrace formation. In: Quaternary of the Thames (ed. D. Bridgland): 17-19. Chapman \& Hall, London.

Bridgland, D.R., 2000. River terrace systems in north-west Europe: an archive of environmental change, uplift, and early human occupation. Quaternary Science Reviews, 19: 1293-1303.

Bridgland, D.R., Gibbard, P.L., Preece, R.C., 1990. Early Middle Pleistocene interglacial deposits at Little Oakley, Essex. Philosophical Transactions of the Royal Society of London, B, 328 307-339.

Bridgland, D.R., Maddy, D., Bates, M., 2004. River terrace sequences: templates for Quaternary geochronology and marine-terrestrial correlation. Journal of Quaternary Science, 19 203-218.

Brown, A.G., 1995. Lateglacial-Holocene sedimentation in lowland temperate environments: floodplain metamorphosis and multiple channel systems. Paläoklimaforschung, Special Issue, 9 $1-15$.

Busschers, F.S., Kasse, C., van Balen, R.T., Vandenberghe, J. Cohen, K.M., Weerts, H.J.T., Wallinga, J., Johns, C., Cleveringa, P., Bunnik, F.P.M., 2007. Late Pleistocene evolution of the Rhine-Meuse system in the southern North Sea basin: imprints of climate change, sea-level oscillation and glacio-isostacy. Quaternary Science Reviews, 26: 3216-3248.

Busschers, F.S., van Balen, R.T., Cohen, K.M., Kasse, C. Weerts, H.J.T., Wallinga, J., Bunnik, F.P.M., 2008. Response of the Rhine-Meuse fluvial system to Saalian ice-sheet dynamics. Boreas, 37: 377-398.

Collins, P.E.F., Fenwick, I.M., Keith-Lucas, D.M., Worsley, P., 1996. Late Devensian river and floodplain dynamics and related environmental change in NW Europe, with particular reference to a site at Woolhampton, Berkshire, England. Journal of Quaternary Science, 11: 357-375.

Cordier, S., Harmand, D., Lauer, T., Voinchet, P., Bahain, J.-J. Frechen, M., 2012. Geochronological reconstruction of the Pleistocene evolution of the Sarre valley (France and Germany) using OSL and ESR techniques. Geomorphology, 165-166: 91-106.

Cordier, S., Frechen, M., Harmand, D., 2014. Dating fluvial erosion: fluvial response to climate change in the Moselle catchment (France, Germany) since the Late Saalian. Boreas, 43: 450-468.

Czubla, P., 2001. Fennoscandian erratics in Quaternary deposits of Middle Poland and their value for stratigraphic purposes (in Polish with English summary). Acta Geographica Lodziensia, $\mathbf{8 0}$ $1-174$.
Czubla, P., 2015. Fennoscandian erratics in glacial sediments of Poland and their research significance (in Polish with English summary). Wydawnictwo Uniwersytetu Łódzkiego.

Dambeck, R., Thiemeyer, H., 2002. Fluvial history of the northern Upper Rhine River (SW Germany) during the Lateglacial and Holocene. Quaternary International, 93-94: 53-63.

Diehl, M., Sirocko, F., 2007. A New Holsteinian pollen record from the Dry Maar at Döttingen (Eifel). Developments in Quaternary Science. 7: 397-416.

Edwards, M.B., Eriksson, K.A., Kier, R.S., 1983. Palaeochannel geometry and flow patterns determined from exhumed Permian point bars in North-Central Texas. Journal of Sedimentary Petrology, 53: 126-1270.

Erkens, G., Dambeck, R., Volleberg, K.P., Bouman, M.T.I.J., Bos, J.A.A., Cohen, K.M., Wallinga, J., Hoek, W.Z., 2009. Fluvial terrace formation in the northern Upper Rhine Graben during the last 20000 years as a result of allogenic controls and autogenic evolution. Geomorphology, 103: 476-495.

Erkens, G., Hoffmann, T., Gerlach, R., Klostermann, J., 2011. Complex fluvial response to Lateglacial and Holocene allogenic forcing in the Lower Rhine Valley (Germany). Quaternary Science Reviews, 30: 611-627.

Evans, J.E., 1991. Facies relationships, alluvial architecture, and paleohydrology of a Paleogene, humid-tropical alluvial-fan system: Chumstick FM., Washington State, USA. Journal of Sedimentary Petrology, 61: 732-755

Falkowski, E., 1982. The pattern of changes in the middle Vistula valley floor. Geographical Studies, Special Issue, 1: 79-92.

Ferguson, R.I., 1987. Hydraulic and sedimentary control of channel pattern. Institute of British Geographers, Special Publication, 18: 125-158.

Florek, W., 1997. Climatic and anthropogenic impulses in the Late Vistulian and Holocene development of the river channels and valleys of the Baltic Coastal Region and Pomerania. Landform Analysis, 1: 41-50.

Folk, R.L., Ward, W.C., 1957. Brazos river bar: a study of significance of grain size parameters. Journal of Sedimentary Petrology, 27: 3-26.

Fuller, I.C., Macklin, M.G., Lewin, J., Passmore, D.G., Wintle, A.G., 1998. River response to high-frequency climate oscillations in S Europe over the past 200 k.y. Geology, 26: 275-278.

Gao, C., Boreham, S., Preece, R.C., Gibbard, P.L., Briant, R.M., 2007. Fluvial response to rapid climate change during the Devensian (Weichselian) Lateglacial in the River Great Ouse, S England, UK. Sedimentary Geology, 202: 193-210.

Gardner, T.W., 1983. Paleohydrology and paleomorphology of a Carboniferous, meandering, fluvial sandstone. Journal of Sedimentary Petrology, 53: 991-1005.

Gębica, P., 2004. The course of fluvial accumulation during the upper Vistulian in Sandomierz Basin (in Polish with English summary). Prace Geograficzne, 193: 1-236.

Gibbard, P.L., Lewin, J., 2002. Climate and related controls on interglacial fluvial sedimentation in lowland Britain. Sedimentary Geology, 151: 187-210.

Gibling, M.R., Rust, B.R., 1993. Alluvial ridge-and-swale topography: a case study from the Morien Group of Atlantic Canada. IAS Special Publication, 17:133-150.

Gibling, M.R., Nanson, G.C., Maroulis, J.C., 1998. Anastomosing river sedimentation in the Channel Country of central Australia. Sedimentology, 45: 595-619.

Goździk, J., 2001. Stratygrafia i paleogeografia osadów czwartorzędowych z środkowo-zachodniej części kopalni Bełchatów z wykorzystaniem morfoskopii ziarn kwarcowych (in Polish). In: Eolizacja osadów jako wskaźnik stratygraficzny czwartorzędu (ed. E. Mycielska-Dowgiałło): 93-124. Uniwersytet Warszawski, Warszawa.

Gradziński, R., Baryła, J., Doktor, M., Gmur, D., Gradziński, M., Kędzior, A., Paszkowski, M., Soja, R., Zieliński, T., Żurek, S., 2003. Vegetation-controlled modern anastomosing system of the upper Narew River (NE Poland) and its sediments. Sedimentary Geology, 157: 253-276. 
Granoszewski, W., 2003. Late Pleistocene vegetation history and climatic changes at Horoszki Duże, Eastern Poland: a palaeobotanical study. Acta Palaeobotanica, Supplement, 4 3-95.

Hijma, M.P., Cohen, K.M., 2011. Holocene transgression of the Rhine river mouth area, The Netherlands/Southern North Sea: Palaeogeography and sequence stratigraphy. Sedimentology, 58: 1453-1485.

Hornung, J., Aigner, T., 1999. Reservoir and aquifer characterization of fluvial architectural elements: Stubensandstein, U. Triassic, SW Germany. Sedimentary Geology, 129: 215-280.

Huisink, M., 1997. Late-glacial sedimentological and morphological changes in a lowland river in response to climatic change: the Maas, S Netherlands. Journal of Quaternary Science, 12 209-223.

Huisink, M., 2000. Changing river styles in response to Weichselian climate changes in the Vacht valley, eastern Netherlands. Sedimentary Geology, 133: 115-134.

Janssens, M.M., Kasse, C., Bohncke, S.J.P., Greaves, H., Cohen, K.M., Wallinga, J., Hoek, W.Z., 2012. Climate-driven fluvial development and valley abandonment at the last glacial-interglacial transition (Oude IJssel-Rhine, Germany). Netherlands Journal of Geosciences, 91: 37-62.

Jersak, J., Sendobry, K., Śnieszko, Z., 1992. Evolution of loess covers in Poland during the post-Warta period) (in Polish with English summary). Prace Naukowe Uniwersytetu Śląskiego, 1227: 1-297.

Kalicki, T., 1996. Phases of increased river activity during the last 3500 years. Geographical Studies, Special Issue, 9: 94-101.

Kalicki, T., Sanko, A.F., 1998. Palaeohydrological changes in the upper Dneper Valley, Belarus, during the last 20,000 years. In: Palaeohydrology and Environmental Change (eds. G. Benito and K.J. Gregory): 125-135. Wiley \& Sons, Chichester.

Kasse, C., Bohncke, S., Vandenberge, J., 1995. Fluvial periglacial environments, climate and vegetation during the Middle Weichselian in the Netherlands with special reference to the Hengelo Interstadial. Medelingen Rijks Geologische Dienst, Nieuwe Serie, 52: 387-413.

Kasse, C., Vanderberghe, J., Van Huissteden, J., Bohncke, S.J.P., Bos, J.A.A., 2003. Sensitivity of Weichselian fluvial systems to climate change (Nochten mine, eastern Germany). Quaternary Science Reviews, 22: 2141-2156.

Koutsodendris, A., Müller, U.C., Pross, J., Brauer, A., Kotthoff U., Lotter, A., 2010. Vegetation dynamics and climate variability during the Holsteinian Interglacial based on a pollen record from Dethlingen (northern Germany). Quaternary Science Reviews, 29: 3298-3307.

Kozarski, S., Gonera, P., Antczak, B., 1988. Valley floor development and paleohydrological change: The Late Vistulian and Holocene history of the Warta River (Poland). In: Lake, Mire and River Environments (eds. G. Lang and C. Schlüchter): 185-203. Balkema, Rotterdam.

Kraus, M. J., Gwinn, B., 1997. Facies and facies architecture of Paleogene floodplain deposits, Willwood Fm., Bighorn Basin Wyoming, USA. Sedimentary Geology, 114: 33-54.

Krumbein, W.C., 1941. Measurement and geological significance of shape and roundness of sedimentary particles. Journal of Sedimentary Petrology, 11: 64-72.

Krupiński, K.M., 2000. Palynostratigraphic correlation of deposits of the Mazovian interglacial in Poland (in Polish with English summary). Prace Państwowego Instytutu Geologicznego, 69: $1-61$.

Krzyszkowski., D., 1991. Vistulian fluviatile sedimentation near Bełchatów, central Poland. Bulletin of the Polish Academy of Sciences, Earth Sciences, 39: 311-329.

Krzyszkowski, D., 1996. Climatic control on Quaternary fluvial sedimentation in the Kleszczów Graben, Central Poland. Quaternary Science Reviews, 15: 315-333.

Labrecque, P.A., Jensen, J.L., Hubbard, S.M., Nielsen, H., 2011. Sedimentology and stratigraphic architecture of a point bar deposit, Lower Cretaceous McMurray Formation, Alberta, Canada. Bulletin of Canadian Petroleum Geology, 59: 147-171.
Lefevre, D., Antoine, P., Somme, J., 1995. Fluvial systems evolution at the upper Pleniglacial/Late Glacial transition and during the Holocene in the N France. Terra Nostra, 2: 157.

Lewandowski, J., 1988. Middle Pleistocene in the upstream Odra valley region: Moravian Gate - Racibórz Basin (synthetical approach) (in Polish with English summary). Przegląd Geologiczny, 424: 465-474.

Lewin, J., Gibbard, P.L., 2010. Quaternary river terraces in England: Forms, sediments and processes. Geomorphology, 120: 293-311.

Lewis, S., Maddy, D., Glenday, S., 2004. The Thames valley sediment conveyor: fluvial system development over the last two interglacial-glacial cycles. Quaternaire, 15: 17-28.

Lindner, L., Marks, L., Nita, M., 2013. Climatostratigraphy of interglacials in Poland: Middle and Upper Pleistocene lower boundaries from a Polish perspective. Quaternary International, 292: 113-123.

Lüttig, G., 1958. Methodische Fragen der Geschiebeforschung. Geologisches Jahrbuch, 75: 361-418.

Mack, G.H., Leeder, M., Perez-Arlucea, M., Bailey, B.D.J., 2003. Early Permian silt-bed fluvial sedimentation in the Orogrande basin of the Ancestral Rocky Mts, New Mexico, USA. Sedimentary Geology, 160: 159-178.

Maizels, J.K., 1983. Proglacial channel systems: Change and thresholds for change over long, intermediate and short time-scales. IAS Special Publication, 6.

Makaske, B., 1998. Anastomosing rivers. Forms, processes and sediments. Nederlandse Geografische Studies, 249: 1-285.

Makaske, B., Weerts, H.J.T., 2005. Muddy lateral accretion and low stream power in a sub-recent confined channel belt, Rhine-Meuse delta, central Netherlands. Sedimentology, 52: 651-668.

Małek, M., Buczek, K., 2009. Szczegółowa mapa geologiczna Polski w skali 1: 50 000, arkusz Łuków (in Polish). Państwowy Instytut Geologiczny, Warszawa.

Małek, M., Pidek, I.A., 2007. Palinostratigraphy of organogenic deposits of new interglacial stands on Łuków Plain (in Polish with English summary). Annales UMCS, B, 62: $43-57$.

Marks, L., Pavlovskaya, I.E., 2003. The Holsteinian Interglacial river network of mid-eastern Poland and western Belarus. Boreas, 32: 337-346.

Marks, L., Pochocka, K., 1999. River valleys of the Eemian Interglacial in central Poland. Geological Quarterly, 43 (2): 163-168.

Marren, P.M., Russell, A.J., Rushmer, E.L., 2009. Sedimentology of a sandur formed by multiple jökulhlaups, Kverkfjöll, Iceland. Sedimentary Geology, 213: 77-88.

Metivier, F., Barrier, L., 2012. Alluvial landscape evolution: what do we know about metamorphosis of gravel-bed meandering and braided streams? In: Gravel-bed Rivers: Processess, Tools, Environments (eds. M. Church, P.M. Biron and A.G. Roy): 474-500. Wiley \& Sons, Chichester.

Miall, A.D., 1978. Lithofacies types and vertical profile models in braided rivers: a summary. In: Fluvial Sedimentology (ed. A.D. Miall). Canadian Society of Petroleum Geologists, Memoir, 5: 597-604.

Miall, A.D., 1985. Architectural-element analysis: a new method of facies analysis applied to fluvial deposits. Earth-Sciences Reviews, 22: 261-308.

Miall, A.D., 1995. Description and interpretation of fluvial deposits: a critical perspective. Discussion. Sedimentology, 42: 379-384.

Miall, A.D., 1996. The Geology of Fluvial Deposits: Sedimentary Facies, Basin Analysis and Petroleum Geology. Springer, Berlin, Heidelberg, New York.

Mojski, J.E., 2005. Ziemie polskie w czwartorzędzie (in Polish). Państwowy Instytut Gegologiczny, Warszawa.

Mol, J., 1995. Weichselian and Holocene river dynamics in relations to climate change in the Halle-Leipziger Tieflandsbucht (Germany). Eiszeitalter und Gegenwart, 45: 32-41.

Mol, J., 1997. Fluvial response to Weichselian climate changes in the Niederlausitz (Germany). Journal of Quaternary Science, 12: $43-60$. 
Mol, J., Vandenberghe, J., Kasse, C., 2000. River response to variations of periglacial climate in midlatitude Europe. Geomorphology, 33: 131-148

Mycielska-Dowgiałło, E., Woronko, B., 1998. Rounding and frosting analysis of quartz sand-grain surfaces and their significance for interpretations (in Polish with English summary). Przegląd Geologiczny, 46: 1275-1281.

Nanson, G.C., Knighton, A.D., 1996. Anabranching rivers: their cause, character and classification. Earth Surface Processes and Landforms, 21: 217-239.

Nanson, G.C., Young, R.W., Price, D.M., Rust, B.R., 1988. Stratigraphy, sedimentology and Late Quaternary chronology of the Channel Country of W Queensland. In: Fluvial Geomorphology of Australia (ed. R.F. Warner): 151-175. Academic Press, Sydney.

Nitychoruk, J., Bińka, K., Hoefs, J., Ruppert, H., Schneider, J., 2005. Climate reconstruction for the Holsteinian Interglacial in eastern Poland and its comparison with isotopic data from $\mathrm{Ma}$ rine Isotope Stage 11. Quaternary Science Reviews, 24 631-644.

Panin, A., Matlakhova, E., 2015. Fluvial chronology in the East European Plain over the last $20 \mathrm{ka}$ and its palaeohydrological implications. Catena, 130: 46-61.

Passega, R., 1964. Grain-size representation by CM patterns as a geological tool. Journal of Sedimentary Petrology, 41: 830-847.

Pidek, I.A., Terpiłowski, S., Małek, M., 2011. Succession of the Mazovian Interglacial near Łuków (E Poland): palynostratigraphic and palaeogeographic approach. Geologija 53: 27-35.

Pidek, I.A., Zieliński, T., Terpiłowski, S., Czubla, P. Hrynowiecka, A., Kusiak, J., Godlewska, A., Zieliński, P. Małek, M., 2014. Unique features of interglacial deposits (MIS 11, E Poland): comparison of palaeobotanical and geological data. In: STRATI 2013, 1st International Congress of Stratigraphy. At the Cutting Edge of Stratigraphy (eds. R. Rocha, J. Pais J.C. Kullberg and S. Finney): 569-572. Springer Geology, 45.

Pisarska-Jamroży, M., Zieliński, T., 2014. Pleistocene sandur rhythms, cycles and megacycles: Interpretation of depositional scenarios and palaeoenvironmental conditions. Boreas, 43 330-348.

Preece, R.C., Parfitt, S.A., Bridgland, D.R., Lewis, S.G., Rowe, P.J., Atkinson, T.C., Candy, I., Debenham, N.C., Penkman, K.E.H., Rhodes, E.J., Schwenninger, J.L., Griffiths, H.I., Whittaker, J.E., Gleed-Owen, G., 2007. Terrestrial environments during MIS 11; evidence from the Palaeolithic site at West Stow, Suffolk, UK. Quaternary Science Reviews, 26: 1236-1300.

Rose, J., 1995. Lateglacial and early Holocene river activity in lowland Britain. Paläoklimaforschung, 14: 51-74.

Rotnicki, K., 1987. Main phases of erosion and accumulation in the middle and lower Prosna valley in the last glacial-interglacial cycle. Geographia Polonica, 53: 53-65.

Sarma, J. N., 2005. Fluvial process and morphology of the Brahmaputra River in Assam, India. Geomorphology, 70: 226-256.

Schumm, S.A., 1971. Fluvial geomorphology: Channel adjustments and river metamorphosis. Water Research, 19: 1-22.

Schumm, S.A., Lichty, R.W., 1963. Channel widening and flood-plain construction along Cimarron River in SW Kansas. U.S.G.S. Professional Paper, 352-D: 71-88.

Shukla, U.K., Singh, I.B., 2004. Signatures of palaeofloods in sandbar-levee deposits, Ganga Plain, India. Journal of the Geological Society of India, 64: 455-460.

Sidorchuk, A., Borisova, O., Panin, A., 2001. Fluvial response to the Late Valdai/Holocene environmental change on the East European Plain. Global and Planetary Change, 28: 303-310.

Sidorchuk, A.Y., Panin, A.V., Borisova, O.K., 2009. Morphology of river channels and surface runoff in the Volga River basin (E European Plain) during the Late Glacial period. Geomorphology, 113: $137-157$
Siegenthaler, C., Huggenberger, P., 1993. Pleistocene Rhine gravel: deposits of a braided river system with dominant pool preservation. Geological Society Special Publications, 75: 147-162.

Smith, D.G., 1987. Meandering river point bar lithofacies models: modern and ancient examples compared. SEPM Special Publications, 39: 83-91.

Starkel, L., 1996. The glacial-interglacial cycle in the evolution of the Vistula River basin (in Polish with English summary). In: Genesis, lithology and stratigraphy of Quaternary deposits, 2 (ed. A. Kostrzewski): 297-305. Geografia, 57. Wydawnictwo Naukowe Uniwersytetu Adama Mickiewicza, Poznań.

Starkel, L., 2002. Change in the frequency of extreme events as the indicator of climatic change in the Holocene (in fluvial systems). Quaternary International, 91: 25-32.

Starkel, L., Gębica, P., Superson, J., 2007. Last Glacial-Interglacial cycle in the evolution of river valleys in southern and central Poland. Quaternary Science Reviews, 26: 2924-2936.

Stewart, D.J., 1981. A meander-belt sandstone of the Lower Cretaceous of S England. Sedimentology, 28: 1-20.

Straffin, E.C., Blum, M.D., Colls, A., Stokes, S., 2000. Alluvial stratigraphy of the Loire and Arroux Rivers, Burgundy, France. Quaternaire, 10: 271-282.

Szumański, A., 1983. Paleochannels of large meanders in the river valleys of the Polish Lowland. Quaternary Studies in Poland, 4: $207-216$

Teisseyre, A.K., 1991. River classification in the light of annalysis of the fluvial system and hydraulic geometry (in Polish with English summary). Prace Geologiczno-Mineralogiczne, 22: 1-210.

Terpiłowski, S., Zieliński, T., Kusiak, J., Pidek, I.A., Czubla, P., Hrynowiecka, A., Godlewska, A., Zieliński, P., Małek, M., 2014. How to resolve the Pleistocene stratigraphic problems by different methods? A case study from E Poland. Geological Quarterly, 58 (2): 235-250.

Thomas, R.G., Smith, D.G., Wood, J.M., Visser, J., Calverley-Range, E.A., Koster, E.H., 1987. Inclined heterolithic stratification - terminology, decription, interpretation and significance. Sedimentary Geology, 53: 123-179.

Tooth, S., Nanson, G.C., 1999. Anabranching rivers on the Northern Plains of arid central Australia. Geomorphology, 29: 211-233.

Turkowska, K., 1988. Évolution des vallées fluviatiles sur le Plateau de Łódź au cours du Quaternaire Tardif (in Polish with French summary). Acta Geographica Lodziensia, 57: 1-157.

Turner, C., 1998. Volcanic maars, long Quaternary sequences and the work of the INQUA Subcommision on European Quaternary Stratigraphy. Quaternary International, 47/48: 41-49.

Turner, C., West, R.G., 1968. The subdivision and zonation of interglacial periods. Eiszeitalter und Gegenwart, 19: 93-101.

Tzedakis, P.C., Andrieu, V., de Beaulieu, J.L., Crowhurst, S., Follieri, M., Hooghiemstra, H., Magri, D., Reille, M., Sadori, L., Shackleton, N.J., Wijmstra, T.A., 1997. Comparison of terrestrial and marine records of changing climate of the last 500,000 years. Earth and Planetary Science Letters, 150: 171-176.

Uhrin, A., Sztanó, O., 2007. Reconstruction of Pliocene fluvial channels feeding Lake Pannon (Gödöllo Hills, Hungary). Geologica Carpathica, 58: 291-300.

Vandenberghe, J., 2001. A typology of Pleistocene cold-based rivers. Quaternary International, 79: 111-121.

Vandenberghe, J., 2002. The relation between climate and river processes, landforms and deposits during the Quaternary. Quaternary International, 91: 17-23.

Vandenberghe, J., 2008. The fluvial cycle at cold-warm-cold transitions in lowland regions: A refinement of theory. Geomorphology, 98: 275-284.

Vandenberghe, J., Kasse, C., Bohnke, S., Kozarski, S., 1994. Climate-related river activity at the Weichselian-Holocene transition: a comparative study of the Warta and Maas rivers. Terra Nova, 6: 478-485. 
Van Huissteden, J., 1990. Tundra rivers of the last glacial: sedimentation and geomorphological processes during the Middle Pleniglacial in Twente, E Netherlands. Mendedelingen Rijsks Geologische Dienst, Nieuwe Serie, 44: 7-138.

Van Steijn, H., Bertran, P., Francou, B., Hétu, B., Texier, J.P., 1995. Models for the genetic and environmental interpretation of stratified deposits: review. Permafrost and Periglacial Processes, 6: 125-146.

Veldkamp, A., Van den Berg, M.W., 1993. Three-dimensional modelling of Quaternary fluvial dynamics in a climo-tectonic dependent system. A case study of the Maas record (Maastricht, The Netherlands). Global and Planetary Change, 8: 203-218.

Vinx, R., Grube, A., Grube, F., 1997. Vergleichende Lithologie, Geschiebeführung und Geochemie eines Prä-Elster-I-Tills von Lieth bei Elmshorn. Leipziger Geowissenschaften, 5: 83-103.
Weerts, H.J.T., Berendsen, H.J.A., 1995. Late Weichselian and Holocene fluvial palaeogeography of the S Rhine-Meuse delta (the Netherlands). Geologie en Mijnbouw, 74: 199-212.

Westaway, R., Maddy, D., Bridgland, D., 2002. Flow in the lower continental crust as a mechanism for the Quaternary uplift of south-east England: constraints from the Thames terrace records. Quaternary Science Reviews, 21: 559-603.

Woronko, B., 2012. Record of aeolian processes in the Pleistocene sandy deposits of middle and north-eastern Poland (in Polish with English summary). Uniwersytet Warszawski, Warszawa.

Zieliński, T., Goździk, J., 2001. Palaeoenvironmental interpretation of a Pleistocene alluvial succession in central Poland: sedimentary facies analysis as a tool for palaeoclimatic inferences. Boreas, 30: 240-253.

Zieliński, T., Pisarska-Jamroży, M., 2012. Which features of deposits should be included in a code and which not? (in Polish with English summary). Przegląd Geologiczny, 60: 387-397. 